\title{
Marine distribution and foraging habitat highlight potential threats at sea for the Endangered Bermuda petrel Pterodroma cahow
}

\author{
André F. Raine ${ }^{1, *}$, Carina Gjerdrum ${ }^{2}$, Isabeau Pratte ${ }^{2}$, Jeremy Madeiros ${ }^{3}$, \\ Jonathan J. Felis ${ }^{4}$, Josh Adams ${ }^{4}$ \\ ${ }^{1}$ Archipelago Research and Conservation, Kauai, Hawai'i 96716, USA \\ ${ }^{2}$ Canadian Wildlife Service, Dartmouth, Nova Scotia B2Y 2N6, Canada \\ ${ }^{3}$ Department of Environment and Natural Resources, Ministry of Home Affairs, Botanical Gardens, 169 South Road, \\ Paget DV04, Bermuda
}

${ }^{4}$ US Geological Survey, Western Ecological Research Center, Santa Cruz Field Station, Santa Cruz, California 95060, USA

\begin{abstract}
Marine spatial planning relies on detailed spatial information of marine areas to ensure effective conservation of species. To enhance our understanding of marine habitat use by the highly pelagic Bermuda petrel Pterodroma cahow, we deployed GPS tags on 6 chick-rearing adults in April 2019 and constructed a habitat suitability model using locations classified as foraging to explore functional responses to a selection of marine environmental variables. We defined 15 trips for 5 individuals, ranging from 1-6 trips per bird, that included both short and long foraging excursions indicative of a dual foraging strategy that optimizes chick feeding and self maintenance. The maximum distance birds flew from Bermuda during foraging trips ranged from 61 to $2513 \mathrm{~km}$ (total trip lengths: 186-14 $051 \mathrm{~km}$ ). Behaviourally deduced foraging habitat was best predicted at shorter distances from the colony, under warmer sea surface temperature, greater sea surface height, and in deeper water compared to transiting locations; our model results indicated that suitable foraging habitat exists beyond the core home range of the population, as far north as the highly productive Gulf Stream frontal system, and within the territorial waters of both the USA and Canada. Our results are crucial to inform management decisions and international conservation efforts by better identifying potential threats encountered at sea by this globally rare seabird and highlighting jurisdictions potentially responsible for mitigating those threats.
\end{abstract}

KEY WORDS: Pterodroma cahow · Foraging behaviour · Marine habitat suitability · GPS tracking · Marine threats $\cdot$ Marine conservation

\section{INTRODUCTION}

Gadfly petrels (Pterodroma spp.) are among the most threatened group of seabirds (Croxall et al. 2012, Rodríguez et al. 2019), with limited available habitat on land, very small population sizes, and threats at colonies that require intensive management and conservation efforts (e.g. Carlile et al. 2003). Limiting the impacts of invasive alien species (Jones et al. 2016, Brooke et al. 2018, Raine et al. 2020b) and protecting and enhancing nest sites (Madeiros et al.

${ }^{*}$ Corresponding author: andreraine@arckauai.com
2014, Gummer et al. 2015) have addressed direct threats at colonies and have helped stabilize population trends. However, detailed information is limited for many of these species at sea (Grémillet \& Boulinier 2009), where additional threats have yet to be identified. To be effective, conservation planning directed at these pelagic seabirds with extensive at-sea distributions extending beyond national boundaries, requires a better understanding of their spatial and temporal use of marine areas (Hays et al. 2019, Beal et al. 2021).

(C) A. F. Raine, Crown in the Right of Canada, the Crown, and outside the USA, the US Government 2021. Open Access under Creative Commons by Attribution Licence. Use, distribution and reproduction are unrestricted. Authors and original publication must be credited.

Publisher: Inter-Research · www.int-res.com 
Several recent studies have deployed tracking devices on gadfly petrels in the Atlantic Ocean to help address gaps in our understanding of their marine habitat use. Year-round distributions of the Bermuda Pterodroma cahow, Zino's P. madeira, Deserta's $P$. deserta, and Cape Verde $P$. feae petrels have been described using data collected from global location sensor (GLS) tags (Madeiros et al. 2012, Ramirez et al. 2016, Ramos et al. 2016). Platform terminal transmitters (PTTs) have been used to define marine-use areas and movement patterns of black-capped petrels P. hasitata (Jodice et al. 2015). More recently, Ventura et al. (2020) described flight behaviour and foraging strategies of breeding Deserta's petrels using global positioning system (GPS) tags, which provided greater spatial resolution and accuracy than both GLS and PTT technologies (Heylen \& Nachtsheim 2018). The resulting analyses that integrated results among species or across multiple years (Madeiros et al. 2012, Ramirez et al. 2016, Ramos et al. 2016, 2017) identified several important marine areas for far-ranging petrels, including the waters located along the east coast of North America (Ramos et al. 2017).

These marine areas also support industrial fisheries (Guiet et al. 2019) where interactions with the birds and competition for small pelagic fish or larger, obligate predatory fishes (that drive prey to the surface) may have negative impacts on petrel populations (Ramos et al. 2017). Additionally, these areas broadly overlap with major shipping lanes (Halpern et al. 2015, Pirotta et al. 2019), potentially increasing risks from chemical inputs, including hydrocarbon spills. Brightly illuminated vessels at sea (Black 2005, Merkel \& Johansen 2011) and offshore oil and gas platforms off the coast of eastern Canada present other potential risks (Ronconi et al. 2015, Lieske et al. 2019), particularly for the nocturnally phototactic Bermuda petrel (BirdLife International 2018) during the breeding season (Ramos et al. 2017). Furthermore, ocean waters off the US east coast, from Maine through the Carolinas, have recently been proposed or developed to support renewable energy sources in the form of offshore wind power (https://www.boem.gov/renewableenergy/renewable-energy-path-forward-atlantic; accessed 2 November 2020). Offshore wind-energy facilities pose a collision risk to birds, and may lead to habitat loss and degradation through displacement from feeding areas (Desholm \& Kahlert 2005, Dierschke et al. 2016).

As recently as 2005, the pelagic range and foraging behaviour of the Bermuda petrel remained almost completely unknown (Madeiros 2005), and our understanding was limited to a small number of observations at sea in the waters around Bermuda and along the eastern seaboard of the US (www.GBIF.org (accessed 9 June 2020) GBIF Occurrence Download https://doi.org/10.15468/dl.2ut9pu); only 2 credible sightings were documented in Canadian waters (McLaren 2012). Increased understanding of Bermuda petrel marine habitat use came from GLS dataloggers deployed during 2009-2012 that revealed 3 primary areas used by adults during the chick-rearing period: the central Atlantic Ocean (northeast of Bermuda), waters off North Carolina, USA, and an area southeast of Nova Scotia, Canada (Madeiros et al. 2014, Ramos et al. 2017). Distinct broad-scale habitat use areas identified during the nonbreeding season included waters near the Azores in the eastern Atlantic, and northwest of Bermuda within $1500 \mathrm{~km}$ of the breeding colony (Madeiros et al. 2014, Ramos et al. 2017). However, the spatial accuracy of GLS data (estimated at ca. 180 km; Phillips et al. 2004) and relatively low temporal resolution (daily positions) permitted only broad-scale habitat descriptions with limited ability to classify movementbased behaviours, define important mesoscale foraging habitat use, assess risks at sea for the species, and define the jurisdictions potentially responsible for mitigating threats.

The Bermuda petrel is listed as Endangered on the IUCN Red List due to its small population size, restricted breeding range, and ongoing threats at the colony (BirdLife International 2018). It is also listed as endangered by the US Endangered Species Act 1973 (USFWS 2009) and in Bermuda, by the Protected Species Act 2003. In Canada, the Bermuda petrel is protected under the Migratory Bird Convention Act, 1994 (SC1994, c 22), which prohibits the killing or disturbance of the Bermuda petrel and the deposition of any substance that is harmful to the bird in waters frequented by the species. However, none of the current legislation provides broad protection for the marine habitat of this species, which would be deemed essential for the survival and recovery of the species. Our goals were to use high-resolution GPS tags to (1) quantify distribution and behaviour of adults at sea during the chick-rearing period, and (2) use an environmentally informed modelling approach to define foraging habitat. We hypothesized that chick-provisioning adults would forage well beyond the territorial waters of Bermuda, into both the USA and Canada, where they would potentially be exposed to offshore energy infrastructure and development. 


\section{MATERIALS AND METHODS}

\subsection{Study species}

The breeding population of the Bermuda petrel was estimated at half a million pairs when Bermuda was first discovered by Portuguese and Spanish mariners in the early 1500s (Lefroy 1981). This was later substantiated by the presence of numerous sub-fossil bones in caves and sandy deposits throughout Bermuda (Shufeldt 1916, 1922, Olson et al. 2005). The population was rapidly decimated by introduced mammalian predators and intensive hunting for food by passing mariners and early human colonists. The population collapsed so rapidly that despite protective legislation passed in 1616, the Bermuda petrel seemingly disappeared by the early 1620s (Lefroy 1981, Madeiros 2005). For more than 300 yr, the Bermuda petrel was believed extinct, until 1951, when a small population was discovered on a few rocky islands in northeast Bermuda (Brinkley \& Sutherland 2020). Through intensive management efforts that addressed land-based threats such as predation by introduced rats Rattus rattus, nest competition with the native whitetailed tropicbird Phaethon lepturus catsbyii, and a lack of suitable nesting sites (Wingate 1977, Carlile et al. 2012), the population has grown from 18 breeding pairs in 1961 (Madeiros et al. 2012) to 134 breeding pairs in 2019-20 (J. Madeiros unpubl. data).

The Bermuda petrel is a medium-sized petrel; adults range in mass from 285 to $590 \mathrm{~g}$, with a wingspan of 890-920 mm (Madeiros 2005). Adults first return to breeding islands in Bermuda in late October to engage in courtship behaviour, mating, and nest maintenance $(76 \%$ of the breeding population now nests within artificial burrows; J. Madeiros unpubl. data). Breeding adults depart for a 5 to $6 \mathrm{wk}$ long, pre-egglaying exodus during which they forage extensively in preparation for egg-laying and incubation (Madeiros et al. 2012). They arrive back on the breeding grounds in early January and incubation of a single egg lasts up to $55 \mathrm{~d}$ and is shared by the male and female. Chicks hatch from late February through March and are fed by both parents during short nocturnal visits to the burrow. Typical among petrels, including Pterodroma spp., provisioning parents engage in a dual-foraging strategy (Weimerskirch et al. 1994) where short trips with provisioning on successive nights alternate with extended, long-duration foraging trips lasting as long as $14 \mathrm{~d}$ (Madeiros 2005). Chicks fledge between mid-May and mid-June at ca. 88-100 d after hatch, and may not return to the colony for 5 or more years (Madeiros 2005). Little is known about their diet, but Bermuda petrels are assumed to feed mainly on small squid, fish, and crustaceans either on the wing (typical among other Pterodroma spp.) or while surface-skimming and during shallow dives (Madeiros 2005).

\subsection{Study site}

Nonsuch Island $\left(32.348^{\circ} \mathrm{N}, 64.663^{\circ} \mathrm{W}\right)$ and Horn Rock $\left(32.343^{\circ} \mathrm{N}, 64.666^{\circ} \mathrm{W}\right)$ are located on the eastern side of Castle Harbour, Bermuda (Madeiros et al. 2012). Nonsuch Island (6 ha) is a recently re-established colony for Bermuda petrels (eradicated by the 1620 s; Carlile et al. 2012) with a breeding population of 24 pairs (J. Madeiros unpubl. data); the re-establishment of the colony on Nonsuch was in part a response to tackling the issue of sea level rise and increased storm surge due to climate change, which has been identified as a major threat to remaining Bermuda petrel colonies located on small, low-lying islets (Wingate \& Talbot 2003, Carlile et al. 2012). Birds on this island nest exclusively in artificial burrows (Madeiros et al. 2014) located on a south-facing slope surrounded by native vegetation (Carlile et al. 2012). Horn Rock (0.3 ha) is located ca. $300 \mathrm{~m}$ southwest of Nonsuch Island and is occupied by 47 pairs, of which 38 nest in artificial burrows (J. Madeiros unpubl. data); Horn Rock is a low-lying (10 m), sparsely vegetated limestone islet frequently inundated by storms and threatened with erosion (Madeiros et al. 2014).

\subsection{GPS tag deployment}

On successive nights from 9 to 13 April 2019, we visited active burrows just before sunset and placed a row of small sticks across the opening of each burrow to provide us with an indication of the arrival of adult birds at the burrow ( $\mathrm{n}=9$ on Nonsuch, 9-11 April; $\mathrm{n}=8$ on Horn Rock, 12-13 April). We visited burrows every hour until dawn and if the sticks were knocked down, we examined the burrow chamber. If a breeding adult was found, we blocked the entrance of the burrow with a stone and the adult was left for $1 \mathrm{~h}$ to allow the chick to be fed before the adult was removed and the tag attached. Chicks were left undisturbed.

We deployed GPS tags (e-Obs Bird Solar, $10 \mathrm{~g}$ ) to 6 chick-rearing adults (mean \pm SD chick age at time of deployment was $39.7 \pm 5.4 \mathrm{~d}$; range $34-49 \mathrm{~d}$ ) located on both islands ( $\mathrm{n}=2$ on Nunsuch; $\mathrm{n}=4$ on Horn 
Rock). We chose the eObs tags as they were the lightest depth-reinforced GPS tags that would give us the highest-resolution data over multiple foraging trips for the study. Obtaining high-resolution data was a critical element to assess where Bermuda petrels were foraging and whether they were entering oil and gas exploration lease areas or associating with oil and gas platforms, all of which are issues crucial for the conservation of the species. Furthermore, the fact that data from tags could remotely download to a base station meant further handling (and associated stress) would not be necessary. We opted for attachment techniques that were previously successful on other similar Pterodroma species (MacLeod et al. 2008, Jodice et al. 2015, Ventura et al. 2020) and thought to be less intrusive than harnessing or subcutaneous wire anchors (Barron et al. 2010). Sutures are not a permanent attachment method (unlike harnesses, for example), with the sutures breaking and the tag falling off after 3-4 mo. This ensured that we would obtain multiple tracks for each bird during this key period of the breeding season (important for understanding whether individual tracks were indicative of the main foraging areas) but not burden the bird with the tag beyond the study period.

Based on information from previous limited tracking of Pterodroma petrels, we alternated tag attachment location to either the back ( $\mathrm{n}=3$; cf. Jodice et al. 2015) or tail ( $\mathrm{n}=3$; cf. Ventura et al. 2020) in an effort to minimize the potential effects of increased drag. For back-mounted tags, we used a modified suture-tape-glue attachment technique (MacLeod et al. 2008, Jodice et al. 2015, Raine et al. 2020a) to attach a 3D-printed plastic platform using 4 surgical sutures and then mounted the tag to the platform with 3 cable ties. For tail-mounted tags (Ventura et al. 2020), the 3D printed platforms were attached to 4 central tail feathers with tape (Tesa 4651). The tag was then cable-tied to the plate through holes located at the front and sides. Total handling time during tagging was 15-35 min per bird, and tag mass (including plastic platform and ties) was 3.6-4.4\% of adult body mass (body mass of tagged birds: $303.3 \pm$ $16.6 \mathrm{~g}[\mathrm{SD}]$; Table 1).

We programmed tags to record locations every 2 min, $24 \mathrm{~h}$ per day at full battery power and every 8 or 10 min (3 tags at each) when battery power was depleted (low power mode). We set tags to timeout if they did not obtain a GPS fix after $2 \mathrm{~min}$. We set the tag transmitting radio interval (how often they attempted to transmit to any nearby base station) to $5 \mathrm{~s}$. We weighed each adult before attaching GPS tags. We also weighed chicks from burrows with a tagged adult $(\mathrm{n}=6)$ and from burrows where no adult was tagged $(\mathrm{n}=14)$ weekly through to fledging. As per existing protocols already in place for this species, if chick mass fell below $250 \mathrm{~g}$ during their final stage of development (6-10 weeks old), they were hand-fed supplemental fish (Sardinella anchovia) to increase their chance of fledging (Carlile et al. 2012).

To test whether tagging the adult had an effect on chick mass gain, we fitted a linear mixed model with an interaction term between chick age and treatment (control vs. GPS) as predictive terms for 2 different chick age groups: between age 10 and $40 \mathrm{~d}$, and post tag-deployment between age 40 and $100 \mathrm{~d}$. We included individual chick as a random effect to account for successive measurements carried out on the same chick, and did not include mass if the chick was receiving supplemental food. We tested for the significance of the interaction using a likelihood ratio test comparing our initial model, which included age and treatment in interaction, to a second model that only included age and treatment as fixed additive terms.

We deployed 2 base stations for remote data downloading: one each on Nonsuch Island and Horn Rock,

Table 1. Summary table describing tag deployment metrics and tag performance from 6 adult Bermuda petrels tagged during the 2018-19 breeding season, and date on which breeding status was confirmed in the year following deployments (2019-20). DNR: did not return to the colony in the following year to breed. Dashes indicate no data transmitted

\begin{tabular}{|c|c|c|c|c|c|c|c|c|c|}
\hline Tag ID & Sex & $\begin{array}{c}\text { Bird } \\
\text { weight } \\
\text { (g) }\end{array}$ & $\begin{array}{c}\text { Mount } \\
\text { position }\end{array}$ & $\begin{array}{c}\text { Tag weight as } \\
\text { percentage of total } \\
\text { bird mass }\end{array}$ & $\begin{array}{l}\text { No. fixes } \\
\text { attempted } \\
\text { by tag }\end{array}$ & $\begin{array}{l}\text { Proportion (\%) } \\
\text { of attempts } \\
\text { with locations }\end{array}$ & $\begin{array}{l}\text { Days } \\
\text { tracked }\end{array}$ & $\begin{array}{l}\text { Chick } \\
\text { fledge } \\
\text { mass }(g)\end{array}$ & $\begin{array}{c}\text { 2019-20 } \\
\text { Breeding } \\
\text { confirmed }\end{array}$ \\
\hline E0002 & Male & 290 & Tail & 4.3 & 1415 & 52 & 37.7 & $306^{a}$ & DNR \\
\hline E0029 & Male & 310 & Back & 3.8 & 21495 & 87 & 51.9 & 258 & 31 Jan 20 \\
\hline E0204 & Male & 330 & Back & 3.6 & 2263 & 86 & 6 Feb & $308^{\mathrm{a}}$ & 5 Nov 19 \\
\hline E0208 & Male & 285 & Tail & 4.4 & - & - & - & 222 & DNR \\
\hline E0258 & Female & 310 & Back & 3.8 & 10546 & 85 & 28.0 & 260 & DNR \\
\hline E0400 & Female & 295 & Tail & 4.2 & 2766 & 58 & 27.0 & $214^{\mathrm{a}}$ & 8 Nov 19 \\
\hline
\end{tabular}


where stations had a clear, unobstructed view of the sea and sufficient exposure to sunlight for solar charging. Data from tags automatically downloaded to a base station when birds returned, allowing for continuous data collection until tags presumably detached from individuals or adults no longer visited their colony. These base stations had the additional benefit that there was no need to recapture the adult birds, thus preventing repeated handling stress.

\subsection{Data processing and analyses}

\subsubsection{Data processing and evaluation}

We archived and uploaded all data files stored on base stations to Movebank.org (Wikelski et al. 2020) to synthesize tracking data from all birds into a single database. We evaluated the performance of each tag by quantifying the total number of days tracked (as measured by last communication of the tag with the base station), number of locational fixes attempted by the tag, and number of successful locational fixes recorded (i.e. the GPS could get a fix and did not time out). We manually identified the start and end times of unique foraging trips from the colony by visually inspecting mapped tracks and addressed any ambiguities (due to lack of GPS locational fixes) by inspecting tag-base station communication and downloading records (recorded by e-obs programming) to determine when birds visited the colony when gaps in locational fixes existed.

\subsubsection{Spatial analyses}

For each Bermuda petrel foraging trip identified, we calculated the trip duration, distance travelled, mean and maximum distance from the colony, time (absolute and proportion of trip) spent in territorial and international waters, distance to nearest oil and gas exploration areas, and production platforms (https://www.cnlopb.ca/information/shapefiles/ and https://www.cnsopb.ns.ca/resource-library/mapsand-coordinates; accessed 26 October 2020), and the distance to the nearest, designated US wind energy area (https://www.boem.gov/oil-gas-energy/boemrenewable-energy-geodatabase; accessed 2 November 2020). We also described the diel patterns of occupancy by individual petrels within territorial and international waters by annotating GPS locations with 'day' (solar angle $>-6^{\circ}$, encompassing daytime and civil twilight) or 'night' (solar angle $\leq-6^{\circ}$ ) based on location and time. All calculations were conducted in R (R Core Team 2020) and ArcGIS (ESRI). We further estimated Bermuda petrel spatial utilization using a kernel density estimator using the 'adehabitatHR' package (Calenge \& Dufour 2006) in R. We tested different smoothing parameter values $(h)$ at $5 \mathrm{~km}$ increments until results formed a contiguous polygon at the $95 \%$ probability contour level when considering all locations (final $h=65 \mathrm{~km}$ ) (Kie 2013). We used the utilization distribution (UD) polygons to describe the core area (50\% UD) and the overall home range (95\% UD) for each petrel and calculated the proportion of the population (UD for all individuals pooled) and proportion of the individual home ranges that overlapped with the exclusive economic zones (EEZs) of the USA and Canada.

\subsubsection{Behavioural classification}

To further detail the spatial ecology of the species at sea, we classified behaviours of Bermuda petrels tracked at sea using the 'Expectation Maximization binary Clustering' method ('EMbC' Package in $\mathrm{R}_{\text {; }}$ Garriga et al. 2016, 2019, Mendez et al. 2020). The $\mathrm{EMbC}$ method is a general purpose, unsupervised multivariate data-clustering algorithm based on maximum likelihood estimation of a Gaussian mixture model (Garriga et al. 2016). The EMbC classification method requires location data collected at a uniform sampling interval for meaningful output and interpretation. Because our tracking data were collected at multiple sampling intervals $(2,8$, and $10 \mathrm{~min})$ and because of variable gaps caused by GPS functionality, we interpolated track segments of sufficient duration to a fixed interval prior to behavioural classification. We identified distinct sequences of locations for which the time between successive points was $<30$ min and then linearly interpolated points in each sequence to a $10 \mathrm{~min}$ interval to standardize sampling rate and prevent fabrication of locations across longer tracking gaps. We pooled locations from all interpolated track sequences that had $\geq 3$ locations (e.g. the minimum required to behaviourally classify at least 1 point) and processed them using the EMbC behavioural classification algorithm. Locations classified using this method fall into 4 categories: low-speedlow-angle (LL), interpreted as sitting on the water; low-speed-high-angle (LH) represented foraging at a small scale; high-speed-high-angle ( $\mathrm{HH})$ represented sinuous, exploratory movements at a larger scale; and high-speed-low-angle (HL) represented directional movements associated with transiting and commut- 
ing. We considered the locations classified as LL and $\mathrm{LH}$ to represent foraging, and those classified $\mathrm{HH}$ and HL to represent transiting.

\subsubsection{Environmental data}

To build our habitat suitability model (see Section 2.4.5), we first extracted environmental variables (Table S1 in the Supplement at www.int-res.com/ articles/suppl/n045p337_supp.pdf) restricted to the study period (11 April to 4 June 2019) from a domain considered representative of foraging Bermuda petrels (as represented by our data). The limits of this domain were as follows; to the east the maximum range reached by an individual during a foraging trip multiplied by 1.1 (Wakefield et al. 2017, Baylis et al. 2019); to the north by that same distance excluding the Gulf of St Lawrence and the Bay of Fundy; to the west by the North American continent; and to the south by the latitude corresponding to the limit of the EEZ of Bermuda (Fig. 1). From this domain, we extracted a suite of dynamic variables including daily sea surface temperature $\left(\mathrm{SST}^{\circ}{ }^{\circ} \mathrm{C}\right)$, daily sea surface height $(\mathrm{SSH}, \mathrm{m})$, finite-size Lyapunov exponent (FSLE, $\mathrm{d}^{-1}$; indicative of water stirring), daily eastward $(u)$ and northward $(v)$ water velocity components $\left(\mathrm{m} \mathrm{s}^{-1}\right)$ (based on altimetry), $8 \mathrm{~d}$ composite of chlorophyll a concentration ( $\mathrm{chl} a, \mathrm{mg} \mathrm{m}^{-3}$ ), and weekly ocean surface winds $\left(\mathrm{m} \mathrm{s}^{-1}\right)$. Given persistent cloud cover, we used an $8 \mathrm{~d}$ chl a composite and filled missing values for each weekly layer by nearestneighbour interpolation. We used the $u$ and $v$ water velocity component to calculate daily eddy kinetic energy (EKE, $\mathrm{m} \mathrm{s}^{-1}$; Table S1) indicative of mesoscale circulation patterns. Surface EKE quantifies the energy associated with water displacement, with higher values corresponding to higher velocity and lower values indicating lower flow energy.

As indices of mesoscale fronts, we also calculated spatially discrete, scale-dependent differences among

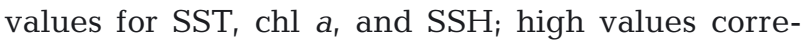
spond with greater differences in values at a given location. Specifically, we used a moving window function to estimate the range in $\mathrm{SST}, \mathrm{chl} a$, and $\mathrm{SSH}$ within neighbourhood cells associated with focal locations. We considered 2 scales for the moving window function: $3 \times 3$ and $15 \times 15$ grid cells (function: $\max [v a l u e]-\min [v a l u e])$. The size of the moving window was chosen to capture mesoscale ( 60$120 \mathrm{~km}$ ) frontal features. Each cell of the moving window corresponded to the spatial resolution of the projected layers ( 8 $\mathrm{km}$ for SST and $\mathrm{SSH}, \sim 4 \mathrm{~km}$ for chl a; Table S1).

We also considered static variables including distance to the colony ( $\mathrm{km}$; great circle distance), water
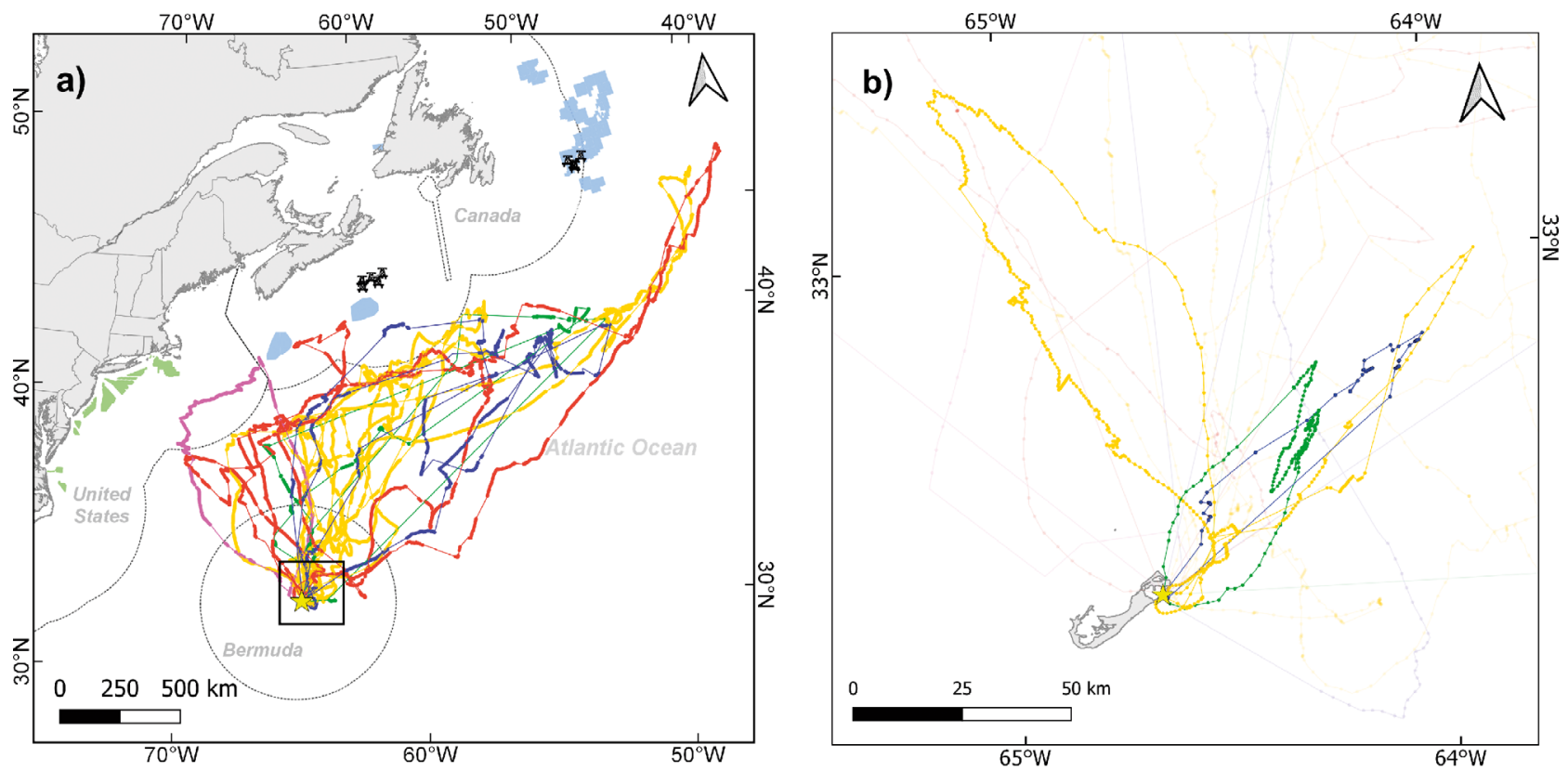

Fig. 1. (a) Foraging trips of individual Bermuda petrels (different colours, $n=5$ ) GPS-tracked during the chick-rearing period from 19 April to 6 June 2019 in Bermuda (colony shown as a yellow star). (b) Although long foraging trips were the norm (n = 11), the birds also took short trips within Bermudian waters $(\mathrm{n}=4)$. Exclusive economic zones for Canada, the USA, and Bermuda are presented (dotted lines), as well as active oil and gas exploration licence areas (blue polygons) and production platforms (black crosses) in Canada and wind energy areas (green polygons) in the USA. Projection is Quebec Lambert EPSG:6622 
depth $(\mathrm{m})$, and the frequency of chlorophyll peak index (FCPI). We calculated FCPI based on monthly chl a values from 2002 through 2019 (Suryan et al. 2012). FCPI provides a measure of long-term deviation from the temporal trend in surface chl a $(9 \mathrm{~km}$ pixel resolution) at each measurement location.

\subsubsection{Habitat suitability model}

To investigate the functional response of Bermuda petrels to their environment, we used the foraging locations ( $\mathrm{LL}$ and $\mathrm{LH}$ ) identified using EMbC ( $\mathrm{n}=$ 2449) to produce a habitat suitability model during the study period (11 April to 4 June 2019) within their defined foraging domain (see Section 2.4.4). Within this defined domain, we randomly sampled 3 background locations (hereafter, pseudo-absences) for each foraging location (i.e. presence; Aarts et al. 2008) after first excluding an area of $1 \mathrm{~km}$ radius around each presence location, and randomly assigned a date to each of those pseudo-absence locations within the study period. Habitat variables were then extracted at each presence and pseudo-absence location at corresponding dates using the R package 'raster' (Hijmans \& van Etten 2012).

To determine which covariates to include in our final predictive model, we fit a logistic regression with binomial distribution to each covariate separately using generalized additive models with the R package 'mgcv' (Wood 2019). To account for the latitudinal gradient in SST across our study area, we also considered a bivariate smoother with SST evaluated by latitude (Forney 2000, Becker et al. 2019). Each model was fit using cubic regression splines with the number of knots initially set to 3 and increased to a maximum of 5 to minimize overfitting and to facilitate interpretation of the response curves. We selected the best model as indicated by the greatest area under the receiver operating curve (AUC) after 10-fold cross validation. Cross validation can mitigate inherent autocorrelation that exists within tracking data (Wood 2006). We further ranked univariate models by AUC. AUC values range from 0.5 (the model is no better than random) to 1 (perfect model fit). To avoid including collinear covariates, we calculated Spearman rank correlations (rho) for each pairwise comparison of covariates and excluded the covariate with absolute rho $\geq 0.7$ that also correlated with one other covariate, or we kept the covariate with the greatest AUC (if no other correlation was detected). We then followed a step-forward selection, adding covariates one by one based on AUC rank, retaining additional covariates if inclusion increased model AUC and decreased Akaike's information criterion (AIC) of the model by $\geq 4$.

We predicted the probability of occurrence of foraging Bermuda petrels at sea within their domain using a grid corresponding to the lowest resolution of our final environmental layers $\left(0.08^{\circ}\right)$. We extracted values from the selected covariates of our final model at the centroid of each daily grid cell. We used the function 'predict.gam' ('mgcv' package) to predict the probability of occurrence of foraging for each of the $55 \mathrm{~d}$ of the tracking study (daily habitat suitability index [HSI]). We averaged the resulting 55 HSI raster layers to generate a final, predictive map corresponding to the average daily probability of occurrence of foraging Bermuda petrels and summarized the error of the spatial prediction by calculating the pixelspecific standard deviation.

\section{RESULTS}

\subsection{Tagging}

We obtained locational data from 5 of 6 tags; birds were tracked for 6.2-51.9 d (729-18780 GPS locations). The tags obtained GPS locations during $85-87 \%$ of fix attempts when mounted on the back of the bird compared with $52-58 \%$ when mounted on the tail (Table 1).

All 6 chicks of tagged adults fledged, although 3 chicks received supplemental fish (Sardinella ancho$v i a$ ) in their final stage of development (mean $\pm \mathrm{SD}$ age when supplemental feeding started: $93 \pm 7$ d) to maintain growth rates and increase their likelihood of survival. An additional 3 chicks of adults not used in our study also received supplemental fish; of these, 1 died before fledging (J. Madeiros unpubl. data). Mean fledging mass of the chicks with a tagged parent (without supplementary feeding) was significantly lower compared to chicks with untagged parents (Welch 2-sample $t$-test: $t_{5.4}=-3.10, \mathrm{p}=0.02$ ). The effect of age on chick mass between age 10 and $40 \mathrm{~d}$ did not differ between control and tagged burrows $\left(\chi^{2}=3.04, p=0.08\right)$, i.e. the interaction between age and treatment was not significant. However, the interaction between chick age and treatment group (i.e. tagged parent or control) on chick mass posttagging (between age 40 and $100 \mathrm{~d}$ ) was significant $\left(\chi^{2}=34.08, \mathrm{p}<0.001\right)$; chicks from burrows with a tagged parent had a lower mass at a given age than chicks from control burrows. 
Monitoring in 2019-20 revealed that 3 of 6 tagged adults did not return to breed during the following year and their untagged partners returned and paired with alternate mates (Table 1). All untagged adults $(\mathrm{n}=14)$ returned to breed in 2019-20, although 1 untagged male was replaced at its burrow prior to egglaying by a younger male.

\subsection{Foraging trips and marine distribution}

We identified 15 trips for 5 individuals (Fig. 1), ranging from 1-6 trips per bird, including both short trips $(\leq 24 \mathrm{~h}$ in duration, departing the colony one night and returning the next; $\mathrm{n}=4$ ) and long trips $(>24 \mathrm{~h}, \mathrm{n}=11$; Table 2). Short trips averaged $( \pm \mathrm{SD})$ $242.0 \pm 63.6 \mathrm{~km}$ in total distance travelled (range $186-328 \mathrm{~km}$ ) and reached an average distance of 47.5 $\pm 15.6 \mathrm{~km}$ (range 27-62 km) from the colony; maximum distances reached during short trips ranged from 61 to $121 \mathrm{~km}$ from the colony (Table 2, Fig. 1b). On average, birds on long trips were absent from the colony for $13.4 \pm 7.2 \mathrm{~d}$ (range $4.2-25.9 \mathrm{~d}$ ) and travelled a total distance of $6248.0 \pm 3443.9 \mathrm{~km}$ (range 2740-14 $051 \mathrm{~km}$; Table 2). Birds on long trips flew an average of $739.4 \pm 247.3 \mathrm{~km}$ from the colony (range 436-1132 km), travelling to a maximum distance from the colony of $1497.7 \pm 577.1 \mathrm{~km}$ (range $774-2513 \mathrm{~km}$; Table 2, Fig. 1a). In general, birds on long trips travelled in a clockwise direction; they headed north after departing from the colony, remained in deeper water (>1000 m depth) off the continental shelf, and returned to the colony from the northeast (Fig. 1a). Three of the 4 longest trips (Table 2) were comprised of shorter 'sub-trips', where birds returned to within ca. $250 \mathrm{~km}$ of the colony after 10.3-12.5 d, then headed out on a second (or third) sub-trip before finally returning to the colony (Table 2, Fig. 2).

In addition to Bermudian waters, GPS locations for tagged Bermuda petrels fell within the EEZs of both the USA and Canada, and within international 'highseas' waters (Fig. 1a). Only 1 of 5 (20.0\%) birds (dur-

Table 2. Summary of foraging trip durations, distances travelled, and mean and maximum distances from colony for 5 adult Bermuda petrels GPS-tracked during the chick-rearing period in April-May 2019. The nearest distances to oil and gas exploration areas (EL), production platforms, and wind energy areas are indicated. Dashes indicate no data transmitted

\begin{tabular}{|c|c|c|c|c|c|c|c|c|c|}
\hline \multirow{2}{*}{$\begin{array}{l}\text { Indivi- } \\
\text { dual }\end{array}$} & \multicolumn{3}{|c|}{ Trip metrics } & \multicolumn{3}{|c|}{ - Distance from colony $\mathrm{km})$} & \multicolumn{3}{|c|}{ Nearest distance $(\mathrm{km})$} \\
\hline & No. & Type & $\begin{array}{l}\text { Duration } \\
\text { (d) }\end{array}$ & $\begin{array}{l}\text { Total distance } \\
\text { travelled }^{\mathrm{a}}(\mathrm{km})\end{array}$ & Mean & Max & $\begin{array}{l}\text { Active } \\
\text { EL }\end{array}$ & $\begin{array}{l}\text { Oil/gas } \\
\text { platform }\end{array}$ & $\begin{array}{l}\text { US wind } \\
\text { energy area }\end{array}$ \\
\hline E0002 & 1 & Short & 0.7 & 203 & 44 & 61 & 1176.2 & 1587.9 & 1254.6 \\
\hline E0002 & 2 & Long & $24.8^{\mathrm{b}}$ & 7801 & 674 & 1675 & 453.9 & 770.8 & 588.4 \\
\hline $\mathrm{E} 0002^{\mathrm{C}}$ & 3 & Long & 12.2 & - & - & - & - & - & - \\
\hline E0029 & 1 & Long & $25.9^{\mathrm{d}}$ & 14051 & 999 & 2369 & 248.4 & 436.9 & 674.7 \\
\hline E0029 & 2 & Long & 10.9 & 5296 & 493 & 1255 & 256.2 & 365.0 & 425.7 \\
\hline E0029 & 3 & Long & 4.2 & 2740 & 506 & 1012 & 368.7 & 543.0 & 853.8 \\
\hline E0029 & 4 & Short & 0.8 & 328 & 62 & 121 & 1095.5 & 1542.5 & 1151.9 \\
\hline E0029 & 5 & Short & 1.0 & 251 & 27 & 102 & 1154.8 & 1552.3 & 1258.8 \\
\hline E0029 & 6 & Long & 9.2 & 3147 & 436 & 774 & 379.8 & 701.1 & 636.1 \\
\hline E0204 & 1 & Long & 6.2 & 2893 & 699 & 1001 & 31.8 & 700.6 & 165.2 \\
\hline E0258 & 1 & Long & 11.1 & 7077 & 1132 & 2513 & 276.4 & 503.6 & 461.8 \\
\hline E0258 & 2 & Long & $16.9^{\mathrm{e}}$ & 8680 & 710 & 1215 & 16.1 & 220.3 & 427.5 \\
\hline E0400 & 1 & Long & 8.0 & 4587 & 673 & 1491 & 364.5 & 586.5 & 754.3 \\
\hline E0400 & 2 & Short & 0.8 & 186 & 57 & 81 & 1173.8 & 1576.5 & 1260.3 \\
\hline E0400 & 3 & Long & $18.2^{\mathrm{f}}$ & 6208 & 1072 & 1672 & 99.5 & 255.2 & 688.2 \\
\hline \multicolumn{10}{|c|}{$\begin{array}{l}\text { aDue to some gaps in GPS tracking (GPS timeout issues or battery depletion), trip distance travelled should be interpreted } \\
\text { as a minimum }\end{array}$} \\
\hline \multirow{3}{*}{\multicolumn{10}{|c|}{$\begin{array}{l}{ }^{\mathrm{b}} \text { After } 10.3 \mathrm{~d} \text { from initial departure from the colony, bird returned to within } 166 \mathrm{~km} \text { of the colony but departed for a second } \\
\text { sub-trip lasting } 14.5 \mathrm{~d} \text { before finally returning to the colony. Trip end time determined from base station download record } \\
{ }^{\mathrm{c}} \text { Trip start and end times determined from base station download record, but no locational information was recorded } \\
\text { d After } 12.5 \mathrm{~d} \text { from its initial departure from the colony, the bird returned to within } 247 \mathrm{~km} \text { of the colony but departed for a } \\
\text { second sub-trip lasting } 6.8 \mathrm{~d} \text { before returning to the same area (within } 254 \mathrm{~km} \text { of colony) without visiting the colony. Bird } \\
\text { departed again for a third sub-trip lasting } 5.2 \mathrm{~d} \text { before finally returning to the colony }\end{array}$}} \\
\hline & & & & & & & & & \\
\hline & & & & & & & & & \\
\hline \multicolumn{10}{|c|}{$\begin{array}{l}\text { eAfter } 11.7 \mathrm{~d} \text { from its initial departure from colony, the bird returned to within } 202 \mathrm{~km} \text { of colony but departed for a second } \\
\text { sub-trip lasting } 4.8 \mathrm{~d} \text { before finally returning to the colony }\end{array}$} \\
\hline${ }^{\mathrm{f}}$ Trip en & ime de & ermined & om base st & n download reco & & & & & \\
\hline
\end{tabular}



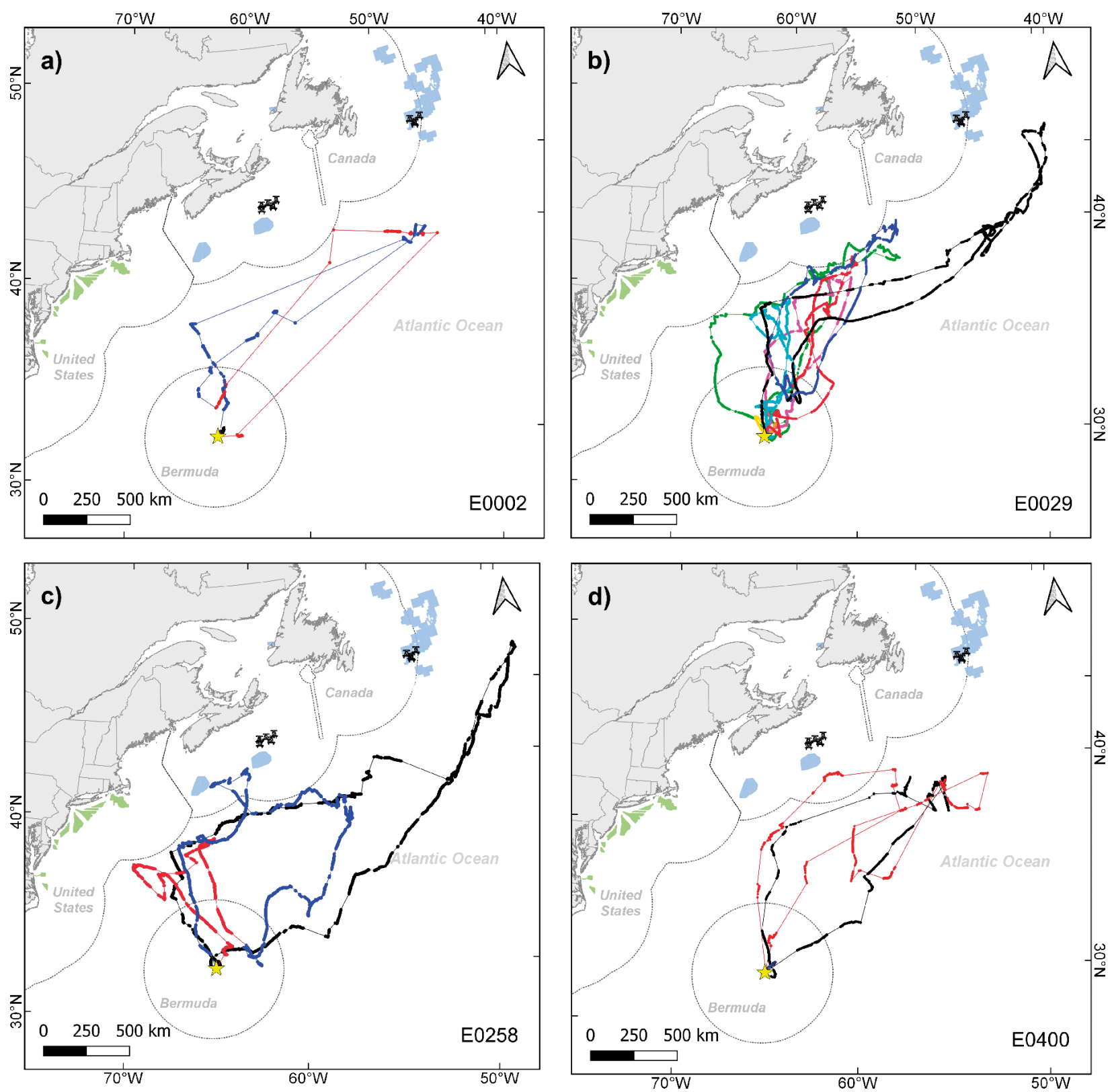

Fig. 2. Successive tracks (different colours) of chick-rearing Bermuda petrels tracked for at least 2 trips (or sub-trips, when birds returned to within ca. $250 \mathrm{~km}$ of colony then returned to the high seas without first returning to the colony; Table 2) within the 2018-19 breeding season. Panels correspond to individual birds: (a) E0002, (b) E0029, (c) E0258, (d) E0400. Other details as in Fig. 1

ing a single trip) entered US territorial waters (Fig. 1a). In comparison, 4 of $5(80.0 \%)$ birds (and 5 of 14 [35.7\%] trips with location information) entered Canadian territorial waters (Fig. 1). and included night-time locations $(46.8 \%$ of the GPS locations obtained from the birds while in Canadian waters occurred at night). Within these waters, the closest a tagged bird came to an oil or gas platform was 220.3 $\mathrm{km}$, and that same individual ventured to within 16.1 $\mathrm{km}$ of an active exploratory licence area (Table 2, Fig. 2c). Within the USA, the closest a tagged bird came to a designated wind energy area was $165.2 \mathrm{~km}$ (Table 2, Fig. 1).

The home range (95\% UD) estimated for all individuals combined spanned ca. 2.5 million $\mathrm{km}^{2}$, with $24.9 \%$ of their area overlapping territorial waters of Bermuda, the USA, or Canada and the remainder within international waters (Fig. 3a). Bermuda accounted for the most territorial overlap $(13.5 \%)$, followed by the USA (6.6\%) and Canada $(4.8 \%)$; the areas of overlap were 354000,172000 , and $126000 \mathrm{~km}^{2}$, respectively (Fig. 3a). Canadian waters 

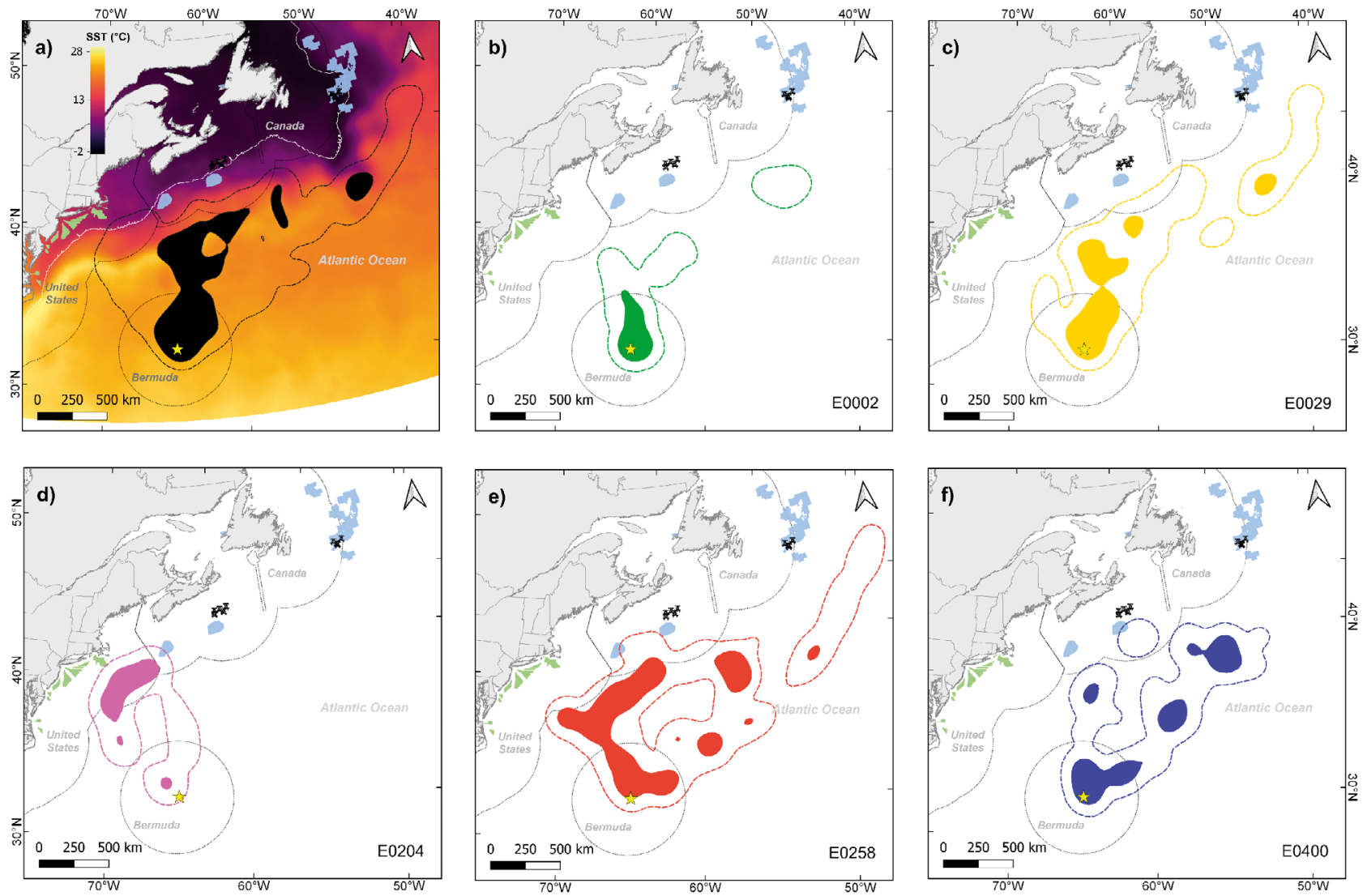

Fig. 3. Estimated kernel utilization distribution (UD; $h=65 \mathrm{~km}$ ) for the 5 Bermuda petrels tracked during the chick-rearing period in 2019 showing $95 \%$ UD (dashed coloured lines in panels b-f; black dashed line in panel a) and $50 \%$ UD (solid coloured patches in panels b-f, black patches in panel a) of all locations obtained for (a) all 5 individuals pooled with daily sea surface temperature (SST, ${ }^{\circ} \mathrm{C}$ ); SST averaged over the study period (11 April to 4 June 2019; warmer colours represent warmer temperatures), and (b-f) for each of the individual birds tracked (E0002, E0029, E0204, E0258, and E0400, respectively). The 500 m isobath is included in panel a (white line) to represent the approximate location of the shelf break. Other details as in Fig. 1

were included within the $95 \%$ UD estimated for 4 of the 5 birds and within the core area (50\% UD) estimated for 2 birds (Fig. 3b-f).

\subsection{Behavioural classification}

We classified a total of 10542 interpolated $10 \mathrm{~min}$ locations into 4 behavioural classes (Table 3): $\mathrm{HH}$ $(\mathrm{n}=2460), \mathrm{HL}(\mathrm{n}=5633), \mathrm{LH}(\mathrm{n}=718)$, and LL $(\mathrm{n}=$ 1731). The proportions of location classes were similar for day $(26 \% \mathrm{HH}, 52 \% \mathrm{HL}, 8 \% \mathrm{LH}, 15 \% \mathrm{LL})$ and night $(19 \% \mathrm{HH}, 56 \% \mathrm{HL}, 5 \% \mathrm{LH}, 20 \% \mathrm{LL})$, with high-speed behaviours (HH, HL) combined accounting for the majority of locations in both diel periods.

\subsection{Habitat suitability model}

Based on AUC, the final model predicting probability of occurrence of foraging (based on LH and LL vs. random) included 4 covariates: distance to colony (Dist2col), SST smoothed by latitude (SST:lat), water depth (Depth), and SSH (Table 4). Following a stepforward procedure, this model explained $53.2 \%$ of the deviance (Table 5). Within the Bermuda petrel domain, the relative habitat suitability for foraging Bermuda petrels was mostly influenced by distance

Table 3. Number of GPS locations from 5 adult Bermuda petrels tracked during the chick-rearing period in April-May 2019 classified into behavioural classes. HH: high speed, high turning angle; HL: high speed, low turning angle; LH: low speed, high turning angle; LL: low speed, low turning angle. Mean \pm SD speed and turning angle are also shown

\begin{tabular}{|lccc|}
\hline $\begin{array}{l}\text { Behavioural } \\
\text { classification }\end{array}$ & $\begin{array}{c}\text { No. GPS } \\
\text { locations }\end{array}$ & $\begin{array}{c}\text { Speed } \\
\left(\mathrm{km} \mathrm{h}^{-1}\right)\end{array}$ & $\begin{array}{c}\text { Turning angle } \\
(\mathrm{rad})\end{array}$ \\
\hline HH & 2460 & $5.01 \pm 3.02$ & $1.07 \pm 0.74$ \\
HL & 5633 & $7.78 \pm 3.45$ & $0.09 \pm 0.09$ \\
LH & 718 & $0.39 \pm 0.24$ & $1.27 \pm 0.81$ \\
LL & 1731 & $0.48 \pm 0.29$ & $0.08 \pm 0.09$ \\
\hline
\end{tabular}


Table 4. Summary of generalized additive model built with single covariates. Shown are the number of knots used in the smooth function $(k)$, percentage of model deviance explained ( $\%$ dev.), and the area under the receiver operative curve (AUC) calculated for each model following 10-fold cross-validation. Covariates in bold were kept in the final model in the order of their AUC score rank. We present estimates for range in sea surface temperature (SST), chlorophyll $a$, and sea surface height (SSH) from a $15 \times 15$ grid cell moving window function. Dist2col: distance to colony; SST:lat: SST smoothed by latitude; FCPI: frequency of chlorophyll peak index; EKE: eddy kinetic energy; FSLE: finite-size Lyapunov exponent

\begin{tabular}{|lccc|}
\hline Covariate & $k$ & \% dev. & AUC \\
\hline Dist2col & $\mathbf{3}$ & $\mathbf{2 9 . 9}$ & $\mathbf{0 . 8 5}$ \\
SST:lat & $\mathbf{5}$ & $\mathbf{1 6 . 1}$ & $\mathbf{0 . 7 4}$ \\
Depth & $\mathbf{5}$ & $\mathbf{1 3 . 5}$ & $\mathbf{0 . 7 4}$ \\
SSH & $\mathbf{3}$ & $\mathbf{8 . 4}$ & $\mathbf{0 . 7 0}$ \\
FCPI & 3 & 6.4 & 0.69 \\
SST $_{0}$ & 5 & 13.9 & 0.69 \\
Chl $a$ range $_{\text {EKE }}$ & 5 & 6.6 & 0.65 \\
SST range & 4 & 2.6 & 0.63 \\
SSH range & 5 & 1.8 & 0.62 \\
Wind speed & 4 & 3.2 & 0.60 \\
Chl a & 5 & 0.9 & 0.60 \\
FSLE & 3 & 3.4 & 0.58 \\
& 5 & 2.1 & 0.57 \\
\hline
\end{tabular}

to the colony, which was negatively related to the probability of occurrence of foraging (Fig. 4a). Foraging Bermuda petrel locations were more likely associated with warmer SST within the domain (Fig. 4b), deeper waters off the North American shelf-break (Fig. 4c), and greater SSH (Fig. 4d). Despite the absence of any association with the continental shelf (<500 m depth) off eastern North America, modelled habitat suitability was greatest around the colony and extended far into the oceanic zone to the limit of the continental shelf break and into both US and Canadian waters (Fig. 5a), although the probability

Table 5. Model selection following step-forward procedure. The model in bold is the final model selected based on increase in the area under the receiver operative curve (AUC) score, decrease in Akaike's information criterion (AIC) score $(\triangle \mathrm{AIC} \geq 4)$, and increase in deviance explained ( $\% \mathrm{dev}$ ) following the successive addition of covariates (defined in Table 4)

\begin{tabular}{|lcrc|}
\hline Model & AUC & AIC & $\%$ dev \\
\hline presence $\sim$ s(Dist2col) & 0.8614 & 7731 & 29.9 \\
presence $\sim$ s(Dist2col) + s(SST:lat) & 0.9372 & 5395 & 51.2 \\
presence $\sim$ s(Dist2col) + s(SST:lat) + s(Depth) & 0.9391 & 5262 & 52.4 \\
presence $\sim$ s(Dist2col) + s(SST:lat) + s(Depth) & $\mathbf{0 . 9 3 9 9}$ & $\mathbf{5 1 8 4}$ & $\mathbf{5 3 . 2}$ \\
$\quad$ + s(SSH) & & & \\
presence $\sim$ s(Dist2col) + s(SST:lat) + s(Depth) & 0.9398 & 5182 & 53.1 \\
$\quad$ + s(SSH) + s(FCPI) & & & \\
\hline
\end{tabular}

of occurrence of foraging was most variable at the northern limits of suitable habitat (Fig. 5b).

\section{DISCUSSION}

\subsection{Marine distribution and behaviour}

Our study provides the first fine-scale distribution data at sea for Bermuda petrels during the breeding season. We tracked 5 birds for an average of $30 \mathrm{~d}$ and obtained 32055 locations. Chick-rearing adults used an extensive area in the western North Atlantic (ca. 2.5 million $\mathrm{km}^{2}$ ) north of Bermuda. Some birds travelled in a clockwise direction as far as the edge of the Canadian continental shelf before returning to Bermuda, presumably following a flyway with favourable wind direction (Adams et al. 2010, Ventura et al. 2020). Gadfly petrels are known for undertaking remarkably long foraging trips (Ramirez et al. 2016, Ramos et al. 2017, Raine \& Driskill 2019) and for using persistent winds to efficiently travel thousands of kilometres at sea (Ventura et al. 2020). Previously, the waters located along the east coast of North America were described as key habitat for breeding Bermuda petrels (Madeiros et al. 2014), but also for other globally threatened Pterodroma species including blackcapped and Deserta's petrels during breeding (Ramos et al. 2017), and Trindade petrels $P$. arminjoniana during their non-breeding season (Krüger et al. 2016). In general, the western North Atlantic supports a diversity of marine predators year-round (Barrett et al. 2006, Hedd et al. 2012, 2018, Gaube et al. 2018, Davis et al. 2020) where warm, salty surface waters are transported northwards within the Gulf Stream to mix with cool, fresh, nutrient-rich deep waters flowing southward within the Deep Western Boundary Current (Puerta et al. 2020).

Our tracking data indicated that Bermuda petrels performed both short ( $1 \mathrm{~d}$ duration) and long ( $>4 \mathrm{~d}$ duration) foraging excursions, indicative of a dual foraging strategy (Weimerskirch et al. 1994), although $97.7 \%$ of their time at sea was spent on long trips. Birds on short trips remained within Bermudian waters, perhaps to increase the feeding frequency of the chick (Weimerskirch et al. 1994). In contrast, birds on long trips travelled to more distant regions far beyond Bermudian territorial waters, a strategy consistent with previous studies of 

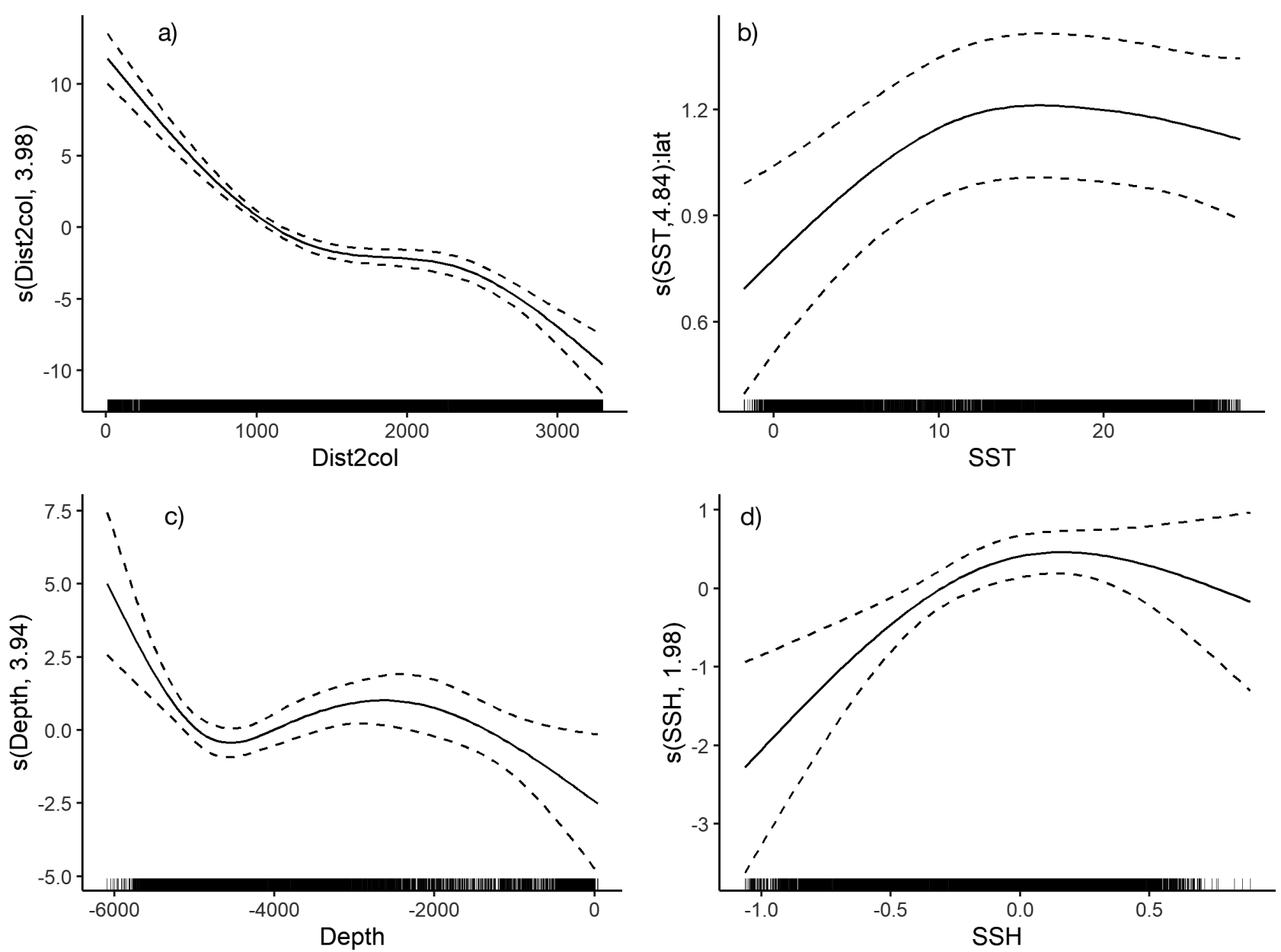

Fig. 4. Model terms for estimated probability of occurrence of foraging Bermuda petrels tracked during the breeding season 2018-19. The $y$-axis represents the function of each term with the effective degrees of freedom (edf) of the smooth term in brackets. 0 on the $y$-axis corresponds to absence of an effect of the predictor variable on the estimated probability of occurrence. Terms included in the generalized additive model were (a) distance to colony (Dist2col; $\mathrm{km}$ ), (b) daily sea surface temperature smoothed by latitude (SST:lat; $\left.{ }^{\circ} \mathrm{C}\right),(\mathrm{c})$ bathymetry (depth; $\left.\mathrm{m}\right)$, and (d) sea surface height (SSH; $\left.\mathrm{m}\right)$; the $y$-axis scale varies to emphasise model fit. The confidence intervals (dashed lines) are shown at 5 standard errors above and below the estimate of the smooth

procellariids (Chaurand \& Weimerskirch 1994, Paiva et al. 2010, Jodice et al. 2015, Shoji et al. 2015) that may provide them access to large-scale, predictable, and potentially richer foraging areas associated with the Gulf Stream. Three of 10 (30\%) long trips showed birds returning to Bermudian waters, but not to their colony to provision chicks, before initiating another long trip to the high seas. It is unknown if such interrupted trips were anomalous, perhaps indicating behavioural alterations resulting from tagging (see Section 4.3). Alternatively, such trips may have resulted from poor flying or feeding conditions (i.e. insufficient wind, insufficient food load), making the trip back to the home colony too costly. Long-term observations at the colony indicate decreased bird activity during nights with relatively little wind (J. Madeiros unpubl. data). Satellite tracking of Hawaiian petrels $P$. sandwichensis indicated that similar, incomplete long trips also do occur (J. Adams unpubl. data).

The behaviour of Bermuda petrels at sea mostly comprised transiting (high speed) movements, and proportions did not vary markedly between day and night, indicating that foraging, as classified here, might occur at any time. Little is known about the diet of Bermuda petrels, but similar to other Pterodroma species (Imber 1973, Klages \& Cooper 1997, Bester et al. 2010, Rayner et al. 2016, Leal et al. 2017), they likely feed on mesopelagic prey including small squid, fish, and crustaceans, and perhaps bioluminescent species that perform diel vertical migrations to the surface at night when they would become more available to the petrels. 


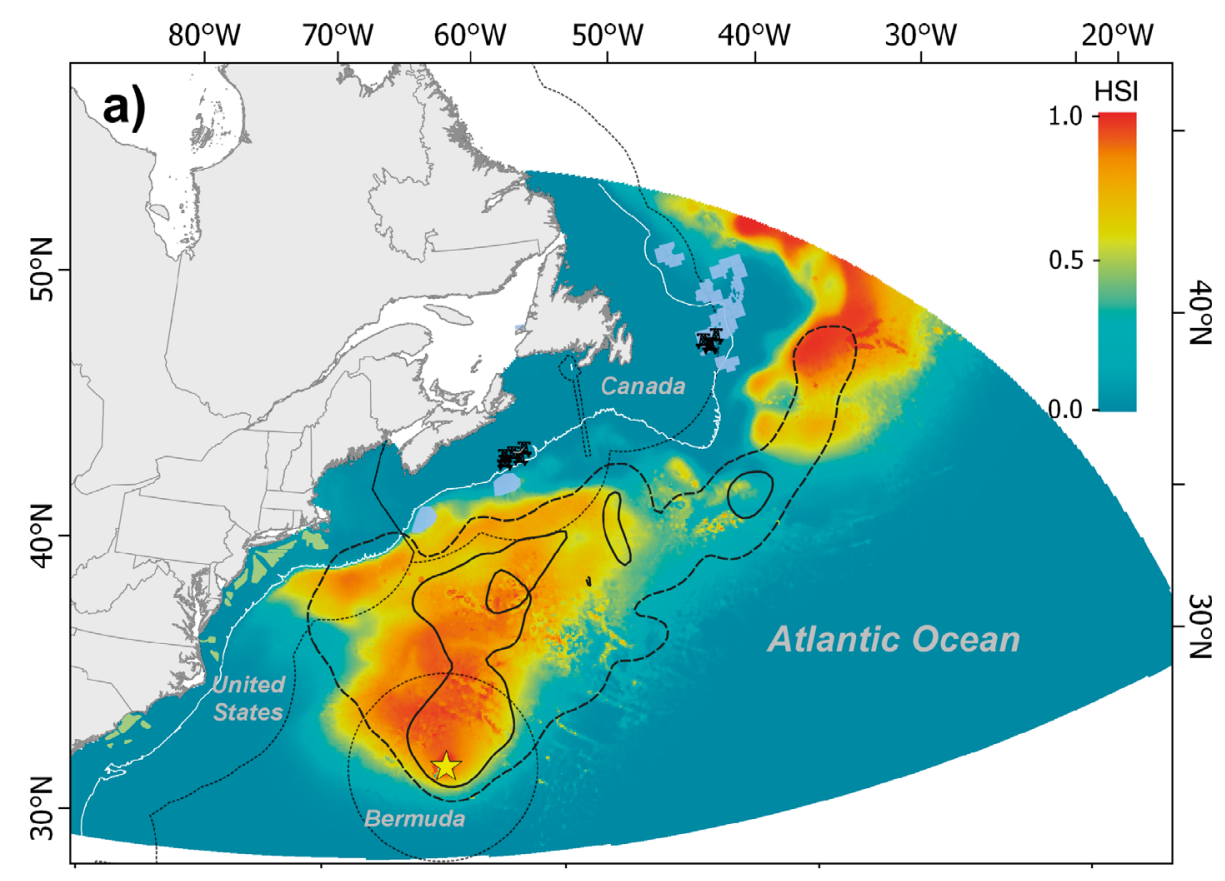

Fig. 5. Spatial habitat predictions of foraging Bermuda petrels tracked from Bermuda (yellow star) during the chick-rearing period (11 April to 4 June 2019; 55 d). (a) Average of daily habitat suitability index (HSI) scaled from 0 (unsuitable) to 1 (highly suitable), and (b) standard deviation of daily HSI. The spatial resolution of the prediction was set to the lowest resolution of our environmental layers (sea surface height, $\mathrm{SSH}$, at $0.08^{\circ}$ ). The $500 \mathrm{~m}$ isobath (white line) represents the approximate location of the shelf break. The thick black lines depict the $50 \%$ (solid) and 95\% (dashed) utilization distributions (see also Fig. 2) of the population. Other details as in Fig. 1

\subsection{Foraging habitat suitability}

Our habitat suitability model highlighted the pelagic distribution of Bermuda petrels during chickrearing; the continental shelf did not appear to be important foraging habitat for the species during this time of the year (Fig. 5a). Model results indicated that the northern limit of foraging roughly corresponded with the Gulf Stream frontal system mark- ing the limit between subtropical and subpolar gyres in the North Atlantic where a sharp temperature front known as the Gulf Stream North Wall (Chi et al. 2019) occurs (Fig. S1). This area of convergence is a dynamic and productive zone (Wenegrat et al. 2020) used by multiple marine predators and consumers, including seabirds (Haney 1986, De Monte et al. 2012), sharks (Gaube et al. 2018, Braun et al. 2019), and neonate sea turtles (Chambault et al. 2017). The 
importance of persistent frontal zones for multiple marine vertebrates makes these regions good candidates for marine conservation areas (Scales et al. 2014).

Despite being a persistent, large-scale oceanographic feature located between Cape Hatteras and the Grand Banks (Seidov et al. 2019), the Gulf Stream trajectory and the latitude of its North Wall front are dynamic, fluctuating in velocity and turbulence and shifting latitudinally among years (McCarthy et al. 2018, Seidov et al. 2019). Dynamic mesoscale features including eddies and meanders shift through space following horizontal water displacement and currents that characterize this region (Kang \& Curchitser 2013, Gaube \& McGillicuddy 2017), and can influence aggregation of foraging marine vertebrates (Cotté et al. 2015, Braun et al. 2019) including seabirds (Hyrenbach et al. 2006, Oliver et al. 2019). This spatiotemporal variability may help explain why we also observed greater variability in our predictions of foraging occurrence in this area, and why our habitat suitability model did not retain covariates that represented mesoscale features (FSLE or EKE) associated with the Gulf Stream, nor covariates that index frontal zones (SST range, chl a range, and SSH range) despite evaluation at multiple scales (results at the sub-mesoscale [ 12$24 \mathrm{~km}$ ] are not presented herein). Alternatively, the large percentage of locations within homeothermic warm Bermudan waters classified as 'foraging' may have masked finer-scale relationships strictly associated with the frontal domain. This might be better resolved in the future with a larger sample size that would allow for modelling short trips separately from long trips, or by evaluating habitat associations within a more focussed domain encapsulating the Gulf Stream frontal area. Nonetheless, the Gulf Stream did appear to be the northern boundary for Bermuda petrel foraging (Fig. S1), and warmer relative SST in particular was an important predictor of foraging occurrence in the final habitat suitability model. Other Pterodroma petrels showed an affinity for warmer SST (Ramos et al. 2016, Krüger et al. 2018); however, the opposite trend (positive association with cooler waters) was observed in albatrosses foraging within the North Pacific Transition Zone (Kappes et al. 2015, Thorne et al. 2015).

In our study, predicted foraging occurrence was most influenced by distance to the colony, which is typical and expected among central-place foragers obligated to return frequently to their breeding colony during the chick-rearing season, and especially for long-ranging seabirds with dual short-trip long-trip strategies. While depth and SSH only explained a small fraction of the deviance in our model, the addition of these variables improved overall model fit. Although seamounts in pelagic areas have been identified as important foraging areas for other marine predators (Morato et al. 2008, Wong \& Whitehead 2014, Kokubun et al. 2015), we have found little support so far for seamounts influencing foraging behaviour among petrels in this study.

Our model indicated that suitable habitat exists beyond the pooled core range (50\% UD), in international waters far from the colonies, but also within the territorial waters of the USA and Canada. However, these areas revealed greater variability in probability of foraging occurrence. Furthermore, our model only explained $53.2 \%$ of the deviance; although not atypical for habitat surface modelling among marine vertebrates (Scales et al. 2014, Virgili et al. 2017, Briscoe et al. 2018, Chavez-Rosales et al. 2019), other unidentified factors such as prevailing wind direction and speed (Ventura et al. 2020), and distribution of prey or obligate predators (e.g. tuna; see Miller et al. 2018) may enhance our ability to define foraging habitat.

\subsection{Potential tag effects}

It is important to address the degree to which our results could have been influenced by tagging effects and to acknowledge that carrying tags may have imposed burdens (Kay et al. 2019) on the petrels in this study. We suspect that tags may have caused decreased food delivery to chicks, and for 3 adult birds it may have suspended breeding in the following year. However, the precise cause of potential impacts (i.e. handling time and disturbance, device effects, timing or length of deployment) is difficult to accurately determine because of the very small sample size. The tags used in this study weighed 3.6$4.4 \%$ of adult body mass, below the $5 \%$ threshold expected to have negative effects on birds (Kenward 2001, Barron et al. 2010), but exceeding the $3 \%$ threshold often adopted for tracking procellariform seabirds (Phillips et al. 2003). Seabirds typically experience large variations in body mass during the breeding period, particularly during chick-rearing, because birds must adjust wing-loading and work harder to supply both themselves and their chicks with enough food (Weimerskirch \& Lys 2000, O'Dwyer et al. 2006, Robertson et al. 2014). Bermuda petrel adult mass decreases up to $29 \%$ from beginning of egg incubation to chick-rearing (J. Madeiros 
unpubl. data), and presumably also within chickfeeding visits when they deliver meals weighing 40-60 g (Carlile et al. 2012). The tag effect results were potentially confounded by the fact that foraging conditions were poor during the 2018-19 breeding season compared with previous years, as indicated by overall lower than average adult and chick weights (J. Madeiros unpubl. data), potentially amplifying any effects of the tags.

In this study, we considered tag positioning in relation to the potential effects of increased drag. From a hydrodynamic perspective, modelling results on seals have shown that tag position can cause variation in drag by up to $11 \%$ and that tag shape is also important (Kay et al. 2019). Conversely, a study on little penguins Eudyptula minor found that tag placement had little effect on diving performance compared with effects of tag size (Ropert-Coudert et al. 2007). As petrels rely on long-distance flights, tag placement presents complex trade-offs regarding drag, weight burden, and balance (see also Vandenabeele et al. 2012, 2014). Bermuda petrels had not previously been tagged with these tags, and in anticipation of potentially long-distance flights, we centred the tags either on the back or the base of the tail to minimize interference with flight, balance, and behaviour (Healy et al. 2004, Vandenabeele et al. 2014). Both positions had been used successfully with the same tags on structurally similar Hawaiian petrels (Raine et al. 2018).

The longer deployments with remote data capture minimized handling time and potentially provided more insight into individual foraging behaviour and habitat use than shorter deployments (Felis et al. 2019, Raine et al. 2020a). However, short-term deployments for sensitive species may minimize energy expenditure associated with carrying tags and have fewer cumulative costs to the study birds (Adams et al. 2009, Barron et al. 2010). We therefore suggest that future efforts to track similar-sized Pterodroma petrels using GPS should not only opt for the smallest tags available, but also minimize tracking durations to decrease cumulative impacts to individuals (Adams et al. 2009). For the Bermuda petrels involved in this study, monitoring for the return of tagged birds in future breeding seasons is also important to determine whether these individuals remain missing (and thus presumed dead), or whether they had taken a breeding season off, something that has been recorded in this species, typically after a pair has successfully fledged chicks throughout several successive years and adult body mass drops below average (J. Madeiros unpubl. data).

\subsection{Conservation implications}

Our study provides new information on the spatial distribution of Bermuda petrels during breeding, where threats related to offshore oil and gas activities or offshore wind-energy infrastructure (OWEI) may co-occur. Gadfly petrels, including Bermuda petrels, are susceptible to disorientation and grounding due to light attraction (Le Corre et al. 2002, Rodríguez et al. 2017, Brinkley \& Sutherland 2020). Offshore oil and gas production platforms and support vessels use artificial lights to illuminate working and living areas, and some installations flare excess gas, which increases the mortality risk to birds that fly near or into the flare (Ronconi et al. 2015, Fraser \& Carter 2018). Accidental oil spills and regular discharges of produced water increase the birds' exposure to oil, often with lethal effects (Wiese et al. 2001, Fraser et al. 2006).

Although there are currently no active oil and gas leases in Atlantic waters off the US coast where Bermuda petrels are known to occur, 4 oil production facilities operate offshore Newfoundland and Labrador (NL), and 32 areas are licensed for exploration (Fig. 1a; https://www.cnlopb.ca/; accessed 2 November 2020). At the time of this study, 6 platforms (2 gas production platforms and 4 satellite, unstaffed platforms) were also located ca. $250 \mathrm{~km}$ from Halifax, Nova Scotia (NS), on the continental shelf (Fig. 1a); however, decommissioning and removal of these platforms is now underway (https://www.cnsopb.ns. ca/offshore-activity/current-activity; accessed 2 November 2020). Two exploration licences remain active in NS waters beyond the shelf break (Fig. 1a), and a moratorium on oil and gas activities on the Canadian portion of Georges Bank, located along the Canada-US maritime boundary off the coast of southwest NS, is set to expire in 2022 (https://www.cnsopb. ns.ca/what-we-do/environmental-protection/specialdesignated-areas; accessed 23 November 2020). None of the birds we tracked approached the platforms in either NL or NS; however, the home range (95\% UD) for 3 of the 5 birds overlapped with at least 1 of the active exploration licence areas in NS waters (Fig. 3). In addition, we predicted that suitable foraging habitat exists within these licensed areas where exploration, and any future production activities, could pose a risk to Bermuda petrels. Fishing vessels, container ships, oil and gas industry support vessels, and cruise ships also add light to the offshore environment in areas where birds may encounter them (Merkel \& Johansen 2011, Ronconi et al. 2015, Krüger et al. 2017), contributing to a cumulative-risk-land- 
scape at sea that includes fishing activity, ship-sourced oil pollution, plastic pollution, and OWEI (Van Sebille et al. 2015, Lieske et al. 2019, 2020).

When considering vulnerability to OWEI in the Atlantic Outer Continental Shelf region of the USA, Bermuda petrels (along with black-capped petrels) were ranked as having the greatest 'population sensitivity' score among all marine birds, had the eighth highest 'collision sensitivity' score, and a medium 'displacement sensitivity' score (Robinson-Willmott et al. 2013). In 2020, active offshore wind energy leases located from the Carolinas through the New York Bight and Gulf of Maine totalled $3652 \mathrm{~km}^{2}$ (Fig.1a; https://www.boem.gov/renewable-energy/; accessed 2 November 2020). With increasing renewable energy goals among states in this area, impacts to Bermuda petrels could be anticipated during the chick-provisioning period, especially if individuals shift their foraging substantially toward the northeast of Bermuda and inshore from the $500 \mathrm{~m}$ isobath. Such displacement was documented for black-capped petrels, which can be steered across the shelf waters, and even inland, during hurricanes, which are predicted to increase in both frequency and magnitude in the future (see Hass et al. 2012). More information at appropriate spatial scales is needed to comprehensively evaluate sensitivity to OWEI and offshore oil and gas activities during the non-breeding and prebreeding periods.

Intensive management and conservation efforts have limited the impacts of colony-based threats for Bermuda petrels, but currently there is no protection for this species at sea. In Bermuda, the species is listed as endangered under the Protected Species Act 2003 and the Protected Species Order 2012 (Bermuda BR 7/2012), which grant both the bird and its nesting habitat full protection. Further protection is legislated under the US Endangered Species Act of 1973 (USFWS 2009), which prohibits the killing or capturing of the petrels, but critical habitat has not been defined nor has a recovery plan been implemented (USFWS 2019). Bermuda petrels are not presently listed as at-risk in Canada; detections of individuals in Canadian waters were considered accidental, although data from adults fitted with GLS tracking devices indicated that birds may occur in Canada, as far north as NL (Madeiros et al. 2014, Ramos et al. 2017). Our results identify important marine habitat in Canada used by Bermuda petrels for foraging during the breeding season, and confirm the species' eligibility for assessment by the Committee on the Status of Endangered Wildlife in Canada (COSEWIC; www.cosewic.ca/index.php/en- ca/assessment-process/; accessed on 20 October 2020), an independent body of experts that assesses wildlife according to a broad range of scientific data. If assessed, a decision whether to list the species under the Species at Risk Act (SARA; S.C. 2002， c. 29) will be made by the federal Cabinet. Recovery strategies and action plans would then be required, which must identify critical habitat and protect it from destruction. Additional high-resolution (i.e. GPS) tracking studies during several years that include birds during other phases of the annual cycle (i.e. pre-laying exodus, incubation, migration, and wintering) would add significant information to improve our understanding of the petrels' range at sea, verify factors we identified as important predictors of distribution, and help define Canada's role in the conservation of this species. Ultimately, how this information is applied to conservation, marine spatial planning, and management interventions will also benefit by considering the impacts of climate change on the spatial ecology of the species (Grémillet \& Boulinier 2009, Hass et al. 2012).

Acknowledgements. All work was authorized under the Research Permit (Licence no. 19-03-19-81) provided by the Government of Bermuda, Ministry of Home Affairs, Department of Environment and Natural Resources. Financial support was provided by the Canadian Wildlife Service, Environment and Climate Change Canada. J.A. and J.J.F. were supported in part by the US Geological Survey Ecosystems Mission Area. We thank Karel Allard for the inspiration to conduct this research, and for valuable discussion and advice during project development and manuscript review; Jennifer Schulien (USGS) for calculating FCPI using code kindly provided by Rob Suryan; Dave Fifield for additional analytical support; Jill Raine for support during the field season; Andrew Boyne for informative discussions pertaining to the protection of birds in Canada; and Morgan Gilmour and Tom Kimball (USGS) and 3 anonymous reviewers who improved this paper. The use of trade, product, or firm names in this publication is for descriptive purposes only and does not imply endorsement by the US Government.

\section{LITERATURE CITED}

Aarts G, MacKenzie M, McConnell B, Fedak M, Matthiopoulos J (2008) Estimating space-use and habitat preference from wildlife telemetry data. Ecography 31:140-160

Adams J, Scott D, McKechnie S, Blackwell G, Shaffer SA, Moller H (2009) Effects of archival tags on reproduction and adult body mass of sooty shearwaters (Puffinus griseus). N Z J Zool 36:355-366

Adams J, Takekawa JY, Carter HR, Yee J (2010) Factors influencing the at-sea distribution of Cassin's auklets (Ptychoramphus aleuticus) that breed in the Channel Islands, California. Auk 127:503-513

* Barrett RH, Chapdelaine G, Anker-Nilssen T, Mosbech A, Montevecchi WA, Reid WV, Veit RR (2006) Seabird numbers and prey consumption in the North Atlantic. ICES J Mar Sci 63:1145-1158 
Barron DG, Brawn JD, Weatherhead PJ (2010) Meta-analysis of transmitter effects on avian behaviour and ecology. Methods Ecol Evol 1:180-187

Baylis AMM, Tierney M, Orben RA, Warwick-Evans V and others (2019) Important at-sea areas of colonial breeding marine predators on the southern Patagonian shelf. Sci Rep 9:8517

Beal M, Dias MP, Phillips RA, Oppel S and others (2021) Global political responsibility for the conservation of albatrosses and large petrels. Sci Adv 7:eabd7225

Becker EA, Forney KA, Redfern JV, Barlow J, Jacox MG, Roberts JJ, Palacios DM (2019) Predicting cetacean abundance and distribution in a changing climate. Divers Distrib 25:626-643

Bester AJ, Priddel D, Klomp NI (2010) Diet and foraging behaviour of the Providence petrel Pterodroma solandri. Mar Ornithol 39:163-172

BirdLife International (2018) Bermuda petrel. Pterodroma cahow. The IUCN Red List of Threatened Species 2018: e. T22698088A132624115. https://dx.doi.org/10.2305/IUCN. UK.2018-2.RLTS.T22698088A132624115.en (accessed 24 Aug 2020)

Black A (2005) Light induced seabird mortality on vessels operating in the Southern Ocean: incidents and mitigation measures. Antarct Sci 17:67-68

Braun CD, Gaube P, Sinclair-Taylor TH, Skomal GB, Thorrold SR (2019) Mesoscale eddies release pelagic sharks from thermal constraints to foraging in the ocean twilight zone. Proc Natl Acad Sci USA 116:17187-17192

Brinkley ES, Sutherland K (2020) Bermuda petrel (Pterodroma cahow), version 2.0. In: Schulenberg TS, Keeney BK, Billerman SM (eds) Birds of the world. Cornell Lab of Ornithology, Ithaca, NY, USA. https://doi.org/10.2173/ bow.berpet.02

* Briscoe DK, Fossette S, Scales KL, Hazen EL and others (2018) Characterizing habitat suitability for a centralplace forager in a dynamic marine environment. Ecol Evol 8:2788-2801

Brooke ML, Bonnaud E, Dilley BJ, Flint EN and others (2018) Seabird population changes following mammal eradications on islands. Anim Conserv 21:3-12

* Calenge C, Dufour AB (2006) Eigenanalysis of selection ratios from animal radio-tracking data. Ecology 87: 2349-2355

Carlile N, Priddel D, Zino F, Natividad C, Wingate DB (2003) A review of four successful recovery programmes for threatened, sub-tropical petrels. Mar Ornithol 31: 185-192

Carlile N, Priddel D, Madeiros J (2012) Establishment of a new, secure colony of Endangered Bermuda petrel Pterodroma cahow by translocation of near-fledged nestlings. Bird Conserv Int 22:46-58

* Chambault P, Roquet F, Benhamou S, Baudena A and others (2017) The Gulf Stream frontal system: a key oceanographic feature in the habitat selection of the leatherback turtle? Deep Sea Res I 123:35-47

Chaurand T, Weimerskirch H (1994) The regular alternation of short and long foraging trips in the blue petrel Halobaena caerulea: a previously undescribed strategy of food provisioning in a pelagic seabird. J Anim Ecol 63: 275-282

Chavez-Rosales S, Palka DL, Garrison LP, Josephson EA (2019) Environmental predictors of habitat suitability and occurrence of cetaceans in the western North Atlantic Ocean. Sci Rep 9:5833
Chi L, Wolfe CLP, Hameed S (2019) The distinction between the Gulf Stream and its North Wall. Geophys Res Lett 46: 8943-8951

* Cotté C, d'Ovidio F, Dragon AC, Guinet C, Lévy M (2015) Flexible preference of southern elephant seals for distinct mesoscale features within the Antarctic Circumpolar Current. Prog Oceanogr 131:46-58

Croxall JP, Butchart SHM, Lascelles B, Stattersfield AJ, Sullivan B, Symes A, Taylor P (2012) Seabird conservation status, threats and priority actions: a global assessment. Bird Conserv Int 22:1-34

* Davis GE, Baumgartner MF, Corkeron PJ, Bell J and others (2020) Exploring movement patterns and changing distributions of baleen whales in the western North Atlantic using a decade of passive acoustic data. Glob Change Biol 26:4812-4840

* De Monte S, Cotté C, D'Ovidio F, Lévy M, Le Corre M, Weimerskirch H (2012) Frigatebird behaviour at the ocean-atmosphere interface: integrating animal behaviour with multi-satellite data. $\mathrm{J} R$ Soc Interface 9: 3351-3358

* Desholm M, Kahlert J (2005) Avian collision risk at an offshore wind farm. Biol Lett 1:296-298

* Dierschke V, Furness RW, Garthe S (2016) Seabirds and offshore wind farms in European waters: avoidance and attraction. Biol Conserv 202:59-68

Felis JJ, Adams J, Hodum PJ, Carle RD, Colodro V (2019) Eastern Pacific migration strategies of pink-footed shearwaters Ardenna creatopus: implications for fisheries interactions and international conservation. Endang Species Res 39:269-282

Forney KA (2000) Environmental models of cetacean abundance: reducing uncertainty in population trends. Conserv Biol 14:1271-1286

Fraser GS, Carter AV (2018) Seabird attraction to artificial light in Newfoundland and Labrador's offshore oil fields: documenting failed regulatory governance. Ocean Yearb 32:267-282

Fraser GS, Russell J, Von Zharen WM (2006) Produced water from offshore oil and gas installations on the Grand Banks, Newfoundland: Are the potential effects to seabirds sufficiently known? Mar Ornithol 34:147-156

* Garriga J, Palmer JRB, Oltra A, Bartumeus F (2016) Expectation-maximization binary clustering for behavioural annotation. PLOS ONE 11:e0151984

* Garriga J, Palmer JRB, Oltra A, Bartumeus F (2019) EMbC: expectation-maximization binary clustering. $\mathrm{R}$ package version 2.0.3. https://CRAN.R-project.org/package=EMbC

Gaube P, McGillicuddy DJ Jr (2017) The influence of Gulf Stream eddies and meanders on near-surface chlorophyll. Deep Sea Res I 122:1-16

Gaube P, Braun CD, Lawson GL, McGillicuddy DJ Jr and others (2018) Mesoscale eddies influence the movements of mature female white sharks in the Gulf Stream and Sargasso Sea. Sci Rep 8:7363

* Grémillet D, Boulinier T (2009) Spatial ecology and conservation of seabirds facing a global climate change: a review. Mar Ecol Prog Ser 391:121-137

* Guiet J, Galbraith E, Kroodsma D, Worm B (2019) Seasonal variability in global industrial fishing effort. PLOS ONE 14:e0216819

Gummer H, Taylor G, Wilson KJ, Rayner MJ (2015) Recovery of the endangered Chatham petrel (Pterodroma axillaris): a review of conservation management techniques from 1990 to 2010. Glob Ecol Conserv 3:310-323 
Halpern BS, Frazier M, Potapenko J, Casey KS and others (2015) Spatial and temporal changes in cumulative human impacts on the world's ocean. Nat Commun 6: 7615

Haney JC (1986) Seabird segregation at Gulf Stream frontal eddies. Mar Ecol Prog Ser 28:279-285

Hass T, Hyman J, Semmens BX (2012) Climate change, heightened hurricane activity, and extinction risk for an endangered tropical seabird, the black-capped petrel Pterodroma hasitata. Mar Ecol Prog Ser 454:251-261

Hays GC, Bailey H, Bograd SJ, Bowen WD and others (2019) Translating marine animal tracking data into conservation policy and management. Trends Ecol Evol 34: 459-473

Healy M, Chiaradia A, Kirkwood R, Dann P (2004) Balance: a neglected factor when attaching external devices to penguins. Mem Natl Inst Polar Res Spec Issue 58: 179-182

Hedd A, Montevecchi WA, Otley H, Phillips RA, Fifield DA (2012) Trans-equatorial migration and habitat use by sooty shearwaters Puffinus griseus from the South Atlantic during the nonbreeding season. Mar Ecol Prog Ser 449:277-290

Hedd A, Pollet IL, Mauck RA, Burke CM and others (2018) Foraging areas, offshore habitat use, and colony overlap by incubating Leach's storm-petrels Oceanodroma leucorhoa in the Northwest Atlantic. PLOS ONE 13: e0194389

Heylen BC, Nachtsheim DA (2018) Bio-telemetry as an essential tool in movement ecology and marine conservation. In: Jungblut $\mathrm{S}$, Liebich $\mathrm{V}$, Bode $\mathrm{M}$ (eds) YOUMARES 8-Oceans across boundaries: learning from each other. Springer, Cham, p 83-107

Hijmans RJ, van Etten J (2012) raster: Geographic analysis and modeling with raster data. $R$ package version 20-12. https://cran.r-project.org/web/packages/raster/index.html (accessed 24 Aug 2020)

*Hyrenbach KD, Veit RR, Weimerskirch H, Hunt GL Jr (2006) Seabird associations with mesoscale eddies: the subtropical Indian Ocean. Mar Ecol Prog Ser 324:271-279

Imber MJ (1973) The food of grey-faced petrels (Pterodroma macroptera gouldi (Hutton)), with special reference to diurnal vertical migration of the prey. J Anim Ecol 42: 645-662

Jodice PGR, Ronconi RA, Rupp E, Wallace GE, Satgé Y (2015) First satellite tracks of the Endangered blackcapped petrel. Endang Species Res 29:23-33

Jones HP, Holmes ND, Butchart SHM, Tershy BR and others (2016) Invasive mammal eradication on islands results in substantial conservation gains. Proc Natl Acad Sci USA 113:4033-4038

Kang D, Curchitser EN (2013) Gulf Stream eddy characteristics in a high-resolution ocean model. J Geophys Res Oceans 118:4474-4487

Kappes MA, Shaffer JA, Tremblay Y, Foley DG, Palacios DM, Bograd SJ, Costa DP (2015) Reproductive constraints influence habitat accessibility, segregation, and preference of sympatric albatross species. Mov Ecol 3: 34

Kay WP, Naumann DS, Bowen HJ, Withers SJ and others (2019) Minimizing the impact of biologging devices: using computational fluid dynamics for optimizing tag design and positioning. Methods Ecol Evol 10:1222-1233

Kenward RE (2001) A manual for wildlife radio tracking, $2^{\text {nd }}$ edn. Academic Press, San Diego, CA
Kie JG (2013) A rule-based ad hoc method for selecting a bandwidth in kernel home-range analyses. Anim Biotelem 1:13

Klages NTW, Cooper J (1997) Diet of the Atlantic petrel Pterodroma incerta during breeding at South Atlantic Gough Island. Mar Ornithol 25:13-16

KKokubun N, Lee WY, Kim JH, Takahashi A (2015) Chinstrap penguin foraging area associated with a seamount in Bransfield Strait, Antarctica. Polar Sci 9:393-400

K Krüger L, Paiva VH, Colabuono FI, Petry MV, Montone RC, Ramos JA (2016) Year-round spatial movements and trophic ecology of Trindade petrels (Pterodroma arminjoniana). J Field Ornithol 87:404-416

Krüger L, Paiva VH, Petry MV, Ramos JA (2017) Strange lights in the nights: using abnormal peaks of light in geolocator data to infer interaction of seabirds with nocturnal fishing vessels. Polar Biol 40:221-226

Krüger L, Pereira JM, Ramirez I, Ramos JA, Paiva VH (2018) How the future climate may modulate the non-breeding distribution of a Vulnerable gadfly petrel. Mar Ecol Prog Ser 599:253-266

* Le Corre M, Ollivier A, Ribes S, Jouventin P (2002) Lightinduced mortality of petrels: a 4-year study from Reunion Island (Indian Ocean). Biol Conserv 105:93-102

* Leal GR, Furness RW, McGill RAR, Santos RA, Bugoni L (2017) Feeding and foraging ecology of Trindade petrels Pterodroma arminjoniana during the breeding period in the South Atlantic Ocean. Mar Biol 164:211

Lefroy JH (1981) Memorials of the discovery and early settlement of the Bermudas or Somers Islands, 1515-1685. Bermuda Historical Society, Bermuda National Trust, Hamilton

KLieske DJ, McFarlane Tranquilla L, Ronconi RA, Abbott S (2019) Synthesizing expert opinion to assess the at-sea risks to seabirds in the western North Atlantic. Biol Conserv 233:41-50

KLieske DJ, McFarlane Tranquilla L, Ronconi RA, Abbott S (2020) 'Seas of risk': assessing the threats to colonialnesting seabirds in Eastern Canada. Mar Policy 115: 103863

MacLeod CJ, Adams J, Lyver P (2008) At-sea distribution of satellite-tracked grey-faced petrels Pterodroma acroptera gouldi, captured on the Ruamaahua (Aldermen) Islands, New Zealand. Pap Proc R Soc Tasman 142:73-88

Madeiros J (2005) Recovery plan for the Bermuda petrel (Cahow) Pterodroma cahow. Department of Conservation Services, Hamilton

* Madeiros J, Carlile N, Priddel D (2012) Breeding biology and population increase of the Endangered Bermuda petrel Pterodroma cahow. Bird Conserv Int 22:35-45

Madeiros J, Flood B, Zufelt K (2014) Conservation and atsea range of Bermuda petrel (Pterodroma cahow). N Am Birds 67:546-557

McCarthy JL, Joyce TM, Josey SA (2018) Gulf Stream variability in the context of quasi-decadal and multidecadal Atlantic climate variability. Geophys Res Lett 45: $11257-11264$

McLaren IA (2012) All the birds of Nova Scotia: status and critical identification. Gaspereau Press Limited, Kentville

*Mendez L, Prudor A, Weimerskirch H (2020) Inter-population variation in the behaviour of adult and juvenile redfooted boobies Sula sula. Ibis 162:460-476

* Merkel FR, Johansen KL (2011) Light-induced bird strikes on vessels in Southwest Greenland. Mar Pollut Bull 62: 2330-2336 
Miller MGR, Carlile N, Scutt Phillips J, McDuie F, Congdon BC (2018) Importance of tropical tuna for seabird foraging over a marine productivity gradient. Mar Ecol Prog Ser 586:233-249

Morato T, Machete M, Kitchingman A, Tempera F and others (2008) Abundance and distribution of seamounts in the Azores. Mar Ecol Prog Ser 357:17-21

O'Dwyer TW, Buttemer WA, Priddel DM, Downing JA (2006) Prolactin, body condition and the cost of good parenting: an interyear study in a long-lived seabird, Gould's petrel (Pterodroma leucoptera). Funct Ecol 20:806-811

Oliver MJ, Kohut JT, Bernard K, Fraser W and others (2019) Central place foragers select ocean surface convergent features despite differing foraging strategies. Sci Rep 9: 157

Olson SL, Wingate DB, Hearty PJ, Grady FV (2005) Prodromus of vertebrate paleontology and geochronology of Bermuda. Proceedings of the International Symposium Insular Vertebrate Evolution; the Palaeontological Approach. Monogr Soc Hist Nat Balears 12:219-232

Paiva VH, Geraldes P, Ramírez I, Meirinho A, Garthe S, Ramos JA (2010) Oceanographic characteristics of areas used by Cory's shearwaters during short and long foraging trips in the North Atlantic. Mar Biol 157:1385-1399

* Phillips RA, Xavier JC, Croxall JP (2003) Effects of satellite transmitters on albatrosses and petrels. Auk 120: 1082-1090

* Phillips RA, Silk JRD, Croxall JP, Afanasyev V, Briggs DR (2004) Accuracy of geolocation estimates for flying seabirds. Mar Ecol Prog Ser 266:265-272

Pirotta V, Grech A, Jonsen ID, Laurance WF, Harcourt RG (2019) Consequences of global shipping traffic for marine giants. Front Ecol Environ 17:39-47

Puerta P, Johnson C, Carreiro-Silva M, Henry LA and others (2020) Influence of water masses on the biodiversity and biogeography of deep-sea benthic ecosystems in the North Atlantic. Front Mar Sci 7:239

R Core Team (2020) R: a language and environment for statistical computing v. 3.5.1. R Foundation for Statistical Computing, Vienna

Raine AF, Driskill S (2019) Assessing colony flyways of Hawaiian petrels on the island of Lana'i. Kaua'i Endangered Seabird Recovery Project (KESRP). University of Hawaii, Department of Land and Natural Resources, Hanapepe, HI

Raine AF, Vynne M, Driskill S, Travers M, Felis J, Adams J (2018) Study of daily movement patterns of Newell's shearwater and Hawaiian petrel in relation to power line collisions: Year Three. Kaua'i Endangered Seabird Recovery Project (KESRP). University of Hawaii, Department of Land and Natural Resources, Hanapepe, HI

Raine AF, Anderson T, Vynne M, Driskill S, Raine H, Adams J (2020a) Post-release survival of fallout Newell's shearwater fledglings from a rescue and rehabilitation program on Kaua'i, Hawai'i. Endang Species Res 43:39-50

Raine AF, Driskill S, Vynne M, Harvey D, Pias K (2020b) Managing the effects of introduced predators on Hawaiian Endangered seabirds. J Wildl Manag 84:425-435

Ramirez I, Paiva VH, Fagundes I, Menezes D and others (2016) Conservation implications of consistent foraging and trophic ecology in a rare petrel species. Anim Conserv 19:139-152

Ramos R, Ramirez I, Paiva VH, Miltao T and others (2016) Global spatial ecology of three closely-related gadfly petrels. Sci Rep 6:23447
Ramos R, Carlile N, Madeiros J, Ramirez I and others (2017) It is the time for oceanic seabirds: tracking year-round distribution of gadfly petrels across the Atlantic Ocean. Divers Distrib 23:794-805

Rayner MJ, Carlile N, Priddel D, Bretagnolle V and others (2016) Niche partitioning by three Pterodroma petrel species during non-breeding in the equatorial Pacific Ocean. Mar Ecol Prog Ser 549:217-229

Robertson GS, Bolton M, Grecian WJ, Monaghan MT (2014) Inter- and intra-year variation in foraging areas of breeding kittiwakes (Rissa tridactyla). Mar Biol 161:1973-1986

Kobinson-Willmott JC, Forcey G, Kent A (2013) The relative vulnerability of migratory bird species to offshore wind energy projects on the Atlantic Outer Continental Shelf: an assessment method and database. Final Report to the US Department of the Interior BOEM, Office of Renewable Energy Programs. OCS Study BOEM 2013-207. https://tethys.pnnl.gov/sites/default/files/publications/ Willmott_et_al_2013.pdf

* Rodríguez A, Moffett J, Revoltós A, Wasiak P and others (2017) Light pollution and seabird fledglings: targeting efforts in rescue programs. J Wildl Manag 81:734-741

Rodríguez A, Arcos JM, Bretagnolle V, Dias MP and others (2019) Future directions in conservation research on petrels and shearwaters. Front Mar Sci 6:94

* Ronconi RA, Allard KA, Taylor PD (2015) Bird interactions with offshore oil and gas platforms: review of impacts and monitoring techniques. J Environ Manag 147:34-45

Ropert-Coudert Y, Knott N, Chiaradia A, Kato A (2007) How do different data logger sizes and attachment positions affect the diving behaviour of little penguins? Deep Sea Res II 54:415-423

Scales KL, Miller PI, Embling CB, Ingram SN, Pirotta E, Votier SC (2014) Mesoscale fronts as foraging habitats: composite front mapping reveals oceanographic drivers of habitat use for a pelagic seabird. J R Soc Interface 11: 20140679

KSeidov D, Mishonov A, Reagan J, Parsons R (2019) Resilience of the Gulf Stream path on decadal and longer timescales. Sci Rep 9:11549

Whoji A, Aris-Brosou S, Fayet A, Padget O, Perrins C, Guilford $T$ (2015) Dual foraging and pair coordination during chick provisioning by Manx shearwaters: empirical evidence supported by a simple model. J Exp Biol 218: 2116-2123

Shufeldt RW (1916) The bird-caves of the Bermudas and their former inhabitants. Ibis 10:623-635

Shufeldt RW (1922) A comparative study of some subfossil remains of birds from Bermuda, including the 'Cahow'. Ann Carnegie Mus 13:333-418

* Suryan RM, Santora JA, Sydeman WJ (2012) New approach for using remotely sensed chlorophyll a to identify seabird hotspots. Mar Ecol Prog Ser 451:213-225

Thorne LH, Hazen EL, Bograd SJ, Foley DG and others (2015) Foraging behavior links climate variability and reproduction in North Pacific albatrosses. Mov Ecol 3:27

USFWS (2009) Species information. USFWS Endangered Species Program. US Fish and Wildlife Service, Washington, DC

USFWS (2019) Cahow or Bermuda petrel (Pterodroma cahow) 5-year review: Addendum 1. Southeast Region RESFO. US Fish and Wildlife Service, Raleigh, NC

*Van Sebille E, Wilcox C, Lebreton I, Maximenko N and others (2015) A global inventory of small floating plastic debris. Environ Res Lett 10:124006 
Vandenabeele SP, Shepard EL, Grogan A, Wilson RP (2012) When three per cent may not be three per cent; deviceequipped seabirds experience variable flight constraints. Mar Biol 159:1-14

Vandenabeele SP, Grundy E, Friswell MI, Grogan A, Votier SC, Wilson RP (2014) Excess baggage for birds: inappropriate placement of tags on gannets changes flight patterns. PLOS ONE 9:e92657

Ventura F, Granadeiro JP, Padget O, Catry P (2020) Gadfly petrels use knowledge of the windscape, not memorized foraging patches, to optimize foraging trips on oceanwide scales. Proc R Soc B 287:20191775

Virgili A, Lambert C, Pettex E, Dorémus G, Van Canneyt O, Ridoux V (2017) Predicting seasonal variations in coastal seabird habitats in the English Channel and the Bay of Biscay. Deep Sea Res II 141:212-223

Wakefield ED, Owen E, Baer J, Carroll MJ and others (2017) Breeding density, fine-scale tracking, and large-scale modeling reveal the regional distribution of four seabird species. Ecol Appl 27:2074-2091

Weimerskirch H, Lys P (2000) Seasonal changes in the provisioning behaviour and mass of male and female wandering albatrosses in relation to the growth of their chick. Polar Biol 23:733-744

Weimerskirch H, Chastel O, Achermann L, Chaurand T, Cuenot-Chaillet F, Hindermeyer X, Judas J (1994) Alternate long and short foraging trips in pelagic seabird parents. Anim Behav 47:472-476

Wenegrat JO, Thomas LN, Sundermeyer MA, Taylor JR and others (2020) Enhanced mixing across the gyre boundary

Editorial responsibility: Rory Wilson,

Swansea, UK

Reviewed by: 3 anonymous referees at the Gulf Stream front. Proc Natl Acad Sci USA 117: 17607-17614

* Wiese FK, Montevecchi WA, Davoren GK, Huettmann F, Diamond AW, Linke J (2001) Seabirds at risk from offshore platforms in the northwest Atlantic. Mar Pollut Bull 42:1285-1290

* Wikelski M, Davidson SC, Kays R (2020) Movebank: archive, analysis and sharing of animal movement data. www. movebank.org (accessed 15 Jan 2020)

Wingate DB (1977) Excluding competitors from Bermuda petrel nesting burrows. In: Temple SA (ed) Proceedings of Symposium on management techniques for preserving endangered birds. University of Wisconsin, Madison, WI, p 93-102

* Wingate DB, Talbot P (2003) Implications of global warming and sea-level rise for coastal nesting birds in Bermuda. In: Pienkowski M (ed) A sense of direction: a conference on conservation in UK Overseas Territories and other small island communities. UK Overseas Territories Conservation Forum, p 247-256. www.ukotcf.org (accessed 21 Oct 2016)

Wong SNP, Whitehead H (2014) Seasonal occurrence of sperm whales (Physeter macrocephalus) around Kelvin Seamount in the Sargasso Sea in relation to oceanographic processes. Deep Sea Res I 91:10-16

Wood SN (2006) Generalized additive models: an introduction with R. CRC Press, New York, NY

* Wood SN (2019) mgcv: Mixed GAM computation vehicle with automatic smoothness estimation. R Package version 18-27. https://cran.r-project.org/web/packages/mgcv/index .html (accessed 24 Aug 2020)

Submitted: November 26, 2020

Accepted: June 3, 2021

Proofs received from author(s): August 16, 2021 